\title{
A systematic review of peer mentoring interventions for people with traumatic brain injury
}

Richard PG Morris, Joanna C Fletcher-Smith \& Kathryn A Radford

Division of Rehabilitation and Ageing, School of Medicine, University of

Nottingham, Queen's Medical Centre, Nottingham, England

Corresponding author:

Richard Morris

Postgraduate Researcher

The University of Nottingham

Division of Rehabilitation and Ageing

School of Medicine

Room B108, Medical School

Queen's Medical Centre

Nottingham NG7 2UH

Email: r.morris@nottingham.ac.uk 


\section{Abstract}

Objective: This systematic review sought evidence concerning the effectiveness of peer mentoring for people with traumatic brain injury.

Data sources: Fourteen electronic databases were searched, including PsycINFO, MEDLINE, CINAHL, EMBASE and the Cochrane Library, from inception to September 21 2016. Ten grey literature databases, PROSPERO, two trials registers, reference lists and author citations were also searched.

Review methods: Studies which employed a model of one-to-one peer mentoring between traumatic brain injury survivors were included. Two reviewers independently screened all titles and abstracts before screening full texts of shortlisted studies. A third reviewer resolved disagreements. Two reviewers independently extracted data and assessed studies for quality and risk of bias.

Results: The search returned 753 records, including one identified through hand searching. 495 records remained after removal of duplicates and 459 were excluded after screening. Full texts were assessed for the remaining 36 
studies and six met the inclusion criteria. All were conducted in the United States between 1996 and 2012 and employed a variety of designs including two randomised controlled trials. 288 people with traumatic brain injury participated in the studies. No significant improvements in social activity level or social network size were found, but significant improvements were shown in areas including behavioural control, mood, coping and quality of life.

Conclusion: There is limited evidence for the effectiveness of peer mentoring after traumatic brain injury. The available evidence comes from small-scale studies, of variable quality, without detailed information on the content of sessions or the 'active ingredient' of the interventions. 


\section{Introduction}

Traumatic brain injury is defined as an injury to the brain caused by a trauma to the head. ${ }^{1}$ Over 1 million people attend United Kingdom emergency departments for head injuries annually, with over 160,000 admitted to hospital. ${ }^{2}$, ${ }^{3}$ Worldwide, it is estimated that 10 million people sustain a traumatic brain injury every year. ${ }^{4}$

Evidence suggests that around $70 \%$ of those with moderate to severe traumatic brain injury experience long-term physical, cognitive, emotional and behavioural problems, ${ }^{5,6}$ while significant numbers of people with minor head injuries also sustain long-term impairments..$^{7-9}$ Brain injury transforms lives dramatically, reducing engagement in activities, impairing relationships and causing social isolation. ${ }^{6}$ Traditional rehabilitation services provide limited support to help people reduce social isolation and resume participation in meaningful activities. Therefore, it is important to investigate new and cost-effective intervention methods.

Peer mentoring is a potentially useful intervention which provides one-to-one support tailored to an individual's needs. It is distinguished in this respect from 
more traditional group peer support methods. The approach is defined as a process through which "an experienced individual encourages and assists a less experienced individual to develop his or her potential within a shared area of interest". ${ }^{10}$ Peer mentoring has been used in a variety of contexts ${ }^{11-13}$ and has shown promise in the management of long-term health conditions such as spinal cord injury. ${ }^{14-18}$ The Brain Injury Association of the United States (BIAUSA) operates well-received peer mentoring programmes across the United States, but evidence of their effectiveness is anecdotal.

This systematic review sought evidence concerning the effectiveness of peer mentoring for people with traumatic brain injury. The primary goal was to inform the design and content of an intervention to be tested in a randomised controlled trial.

\section{Methods}

This review was carried out in accordance with the Preferred Reporting Items for Systematic Reviews and Meta-Analyses (PRISMA) guidelines ${ }^{19}$ and a protocol was registered on the PROSPERO International Prospective Register of Systematic Reviews. ${ }^{20}$ 
Studies of any design which employed a model of one-to-one peer mentoring between traumatic brain injury survivors were included. Studies were excluded if they employed group support models or exclusively used non-traumatic brain injury survivors in either mentor or mentee roles (including professionals, lay people or survivors of other forms of acquired brain injury). Conference abstracts (containing sufficient information) and grey literature were included.

Literature searches were developed across a range of databases using indexing terms (e.g., medical subject headings and Embase's Emtree thesaurus) and text words relating to traumatic brain injury and peer mentoring. Social and leisure activity related terms were not searched in order to keep the search broad and avoid excluding any relevant studies. The search strategy was adapted to the requirements of each database. No wildcards or truncations were used.

The following 14 medical, health, social care and psychology databases were searched from time of inception to September 212016 (see appendix 1 for examples of the search strategy): 
ASSIA: Applied Social Sciences Index and Abstracts (ProQuest: 1987 current); MEDLINE (Ovid: 1946 to current); PsycINFO (Ovid: 1806 to current); CINAHL with Full Text (EBSCOHost: 1981 to current); EMBASE (Ovid: 1974 current); AMED (Ovid: 1985 - current); HMIC (Ovid: 1979 - current); ERIC (EBSCO: 1985 - current); IBSS: International Bibliography of Social Sciences (Proquest: 1951 - current); Web of Science Core Collection (Thomson Reuters: 1898 - current); Cochrane Library (Wiley: 1996 - current); Scopus (Elsevier: 1966 - current); Joanna Briggs Institute (Ovid: 1998 - current); MEDLINE InProcess \& Other Non-Indexed Citations (Ovid: September 21 2016).

A search was conducted in the PROSPERO International Prospective Register of Systematic Reviews for ongoing reviews in the same topic area. Other research in progress was identified through Current Controlled Trials (www.controlled-trials.com) and Clinical Trials (www.clinicaltrials.gov) websites. Authors of any prospective studies were contacted. Grey literature searches were performed in Google Scholar, Google, Open Grey, the British Library Catalogue, US National Library of Congress, PsycExtra, Mednar, the TRIP Database, OAlster and PAIS International. 
Reference lists of selected papers were hand searched. Citations for the authors of included studies were undertaken using the SCOPUS and Google Scholar citation search facilities.

Search results were exported directly into EndNote X7, with additional results added and duplicates removed. Two reviewers independently screened all titles and abstracts for relevance. Full texts were obtained for all potentially relevant articles. A third reviewer resolved any uncertainties regarding inclusion and authors were contacted when necessary for further information.

Data were extracted relating to aspects of study design and participant characteristics; details of the intervention (including details of social and leisure re-engagement); outcome measures; results and conclusions. Two reviewers extracted data independently using a bespoke data extraction form and assessed studies for quality and risk of bias using the Mixed Methods Appraisal Tool. ${ }^{21}$ Meta-analysis was inappropriate due to the scarcity of studies and heterogeneity of designs. Therefore, a descriptive synthesis of the data was undertaken. 


\section{Results}

The database search returned 752 records with one further study identified through hand searching of reference lists. No studies were identified from the grey literature search or through citation searches of authors. 495 records remained after removal of duplicates and 459 were excluded after screening. Full texts were obtained where available for the remaining 36 records and 30 were excluded (see Appendix 2 for reasons) leaving a total of six studies to be included in the review. Figure 1 shows the flow diagram of the selection process.

\section{Insert Figure 1 here}

Appendices three, four and five provide details of studies included in the review and their findings.

\section{Quality assessment of included studies}

The studies were of low quality according to Mixed Methods Appraisal Tool criteria. Randomisation procedures and allocation concealment in the randomised controlled trials were poorly reported or not reported at all, 
indicating risk of bias. Some of the papers combined description of an overarching peer mentoring programme with description of the research study itself, which often made quality assessment difficult. Both reviewers were forced to select 'Can't tell' for many of the criteria on the Mixed Methods Appraisal Tool. This indicated low quality of reporting on many aspects of the studies and also meant that it was inappropriate to give each one a numerical score for the Mixed Methods Appraisal Tool.

\section{Study design and participant characteristics (see Appendix three)}

All six included studies were conducted in the United States between 1996 and 2012, two in San Jose, ${ }^{22,} 23$ two in New York, ${ }^{24,25}$ one in Detroit ${ }^{26}$ and one in Houston. ${ }^{27}$ A variety of study designs were employed including one single centre pilot randomised controlled trial, ${ }^{27}$ one single centre randomised controlled trial, ${ }^{26}$ one quasi-experimental study, ${ }^{25}$ one before-and-after design, ${ }^{22}$ one concurrent mixed methods design ${ }^{24}$ and one service description. ${ }^{23}$ All interventions took place in a community setting.

Information provided on participant numbers and demographics varied widely among the studies. Only one provided a detailed demographic breakdown of 
both mentors and mentees, including by injury severity. ${ }^{27} \mathrm{~A}$ total of 288 people with traumatic brain injury participated across the studies (excluding the Moreci paper which wasn't a research project and didn't report numbers). Some studies also looked at mentoring for significant others ${ }^{24-26}$ but this paper focuses on traumatic brain injury survivors.

Mentor eligibility characteristics included social competency, absence of psychiatric issues or criminal history, willingness, motivation, commitment, empathy, insight and ability to listen and talk openly. There were differences between all the studies in the criteria employed. One project hired mentors as contingent employees. ${ }^{26}$ This was cited as a method of maximising mentor engagement and improving on the studies of Struchen et al and Hibbard et al.

Only one study reported detailed criteria for mentee eligibility. ${ }^{24}$ The others reported few criteria other than age and having sustained a traumatic brain injury. 


\section{Details of intervention (see Appendix four)}

One study aimed specifically at improving social integration and social participation. ${ }^{27}$ Other clearly defined aims were; to improve emotional wellbeing, post-injury quality of life and community integration;26 reducing isolation by providing social support and validation of personal experience; $; 4$ and improving individuals' abilities to access and utilise community services. ${ }^{22}$ Hibbard et al (2002) were the only authors to describe an underpinning theory, or conceptual framework for their study. ${ }^{24}$ This was participatory action research, ${ }^{28,}{ }^{29}$ which seeks to engage community members in the research process and involve them as active participants. Hanks et al also briefly mention participatory action research but only in relation to the development of the questionnaire for the study.

Limited information was provided on the content of mentoring sessions other than topics intended for discussion, which included emotional wellbeing, postinjury quality of life and community integration. ${ }^{26}$ Support staff employed included psychologists (acting as supervisors, trainers and emergency contacts), ${ }^{22,}, 26,27$ programme co-ordinators ${ }^{22,26}$ and a vocational counsellor. ${ }^{22}$ 
The timing of the interventions post-injury varied. One study provided the intervention within two days of discharge from rehabilitation ${ }^{26}$ and another while still in the rehabilitation unit. ${ }^{23}$ Mentees in one study were reported to be a mean of 503 days post-injury ${ }^{22}$ (although this does not specify those with brain injury), and another a median of 1.6 years post-injury. ${ }^{27}$ The ways these figures are reported are inconsistent and it isn't possible to provide a range of time postinjury for participants in all studies. This also applies to the mentors in the studies. One study required mentors to be a minimum of two years post-injury, ${ }^{22}$ while one reported mentors to be a median of 6.2 years post-injury. ${ }^{27}$ Others provided few details.

The criteria by which pairs were matched varied across the studies and included age, gender, role (traumatic brain injury survivor/carer), interests, background, injury effects and geographic area. Two studies relied on the judgement of the study team to provide a mentor best suited for the needs of the mentee. ${ }^{24,27}$

Frequency, duration and intensity of the interventions varied considerably within and between studies. Some researchers established guidelines for minimum numbers of contacts, ${ }^{22,} 26,27$ but these were rarely met. Only one paper provided 
details of the time duration of contacts. ${ }^{26}$ Duration of partnerships varied from three months ${ }^{27}$ to indefinite ${ }^{24}$ (excluding the Moreci service description paper), while reported number of contacts ranged from $1-108 .{ }^{24,26,27}$ The nature of the contacts was generally left up to the participants and could be in-person, telephone or email (Struchen et al allowed a variety of contact methods but only detailed numbers of in-person contacts). The actual content of the sessions was not recorded and isn't reported in any of the papers.

Detailed information on mentor training sessions was provided in several papers. ${ }^{23,} 24,26,27$ Common elements of training included communication skills, listening skills, advocacy, knowledge of traumatic brain injury, and knowledge of community resources. Only one paper mentioned training mentors to handle crisis situations. ${ }^{27}$ Regular refresher sessions were described as important.

There was considerable overlap between the programmes in the logistical challenges they encountered. These can be summarised as follows:

- Problems scheduling times and locations for meetings

- Budgeting for transport

- Identifying suitable mentors

- Providing sufficient staff support time 
- Making allowances for the mentors' cognitive difficulties

- Partners living too far apart

- Too many matching criteria

- Loss of participants' interest due to delay between enrolment and matching

- Lack of accessible meeting locations

- Lack of potential participants' interest in the research aspect of the programmes

- Difficulty recruiting participants from diverse socio-demographic/ethnic groups and people with minor brain injury

- Inability to identify the mechanisms influencing study outcomes

Only one study looked specifically at improving social integration and participation. ${ }^{27}$ Other studies included aspects of community integration, social support and reducing isolation as among the aims of their projects and included measures of these factors. ${ }^{22,24,26}$ 
Outcome measures, follow-up periods, results and conclusions (see Appendix five)

The Craig Handicap Assessment and Reporting Technique Short Form (CHART-SF) $)^{30}$ and the Diener Satisfaction with Life Scale ${ }^{31}$ were administered in two studies. ${ }^{22,27}$ All papers (with the exception of Moreci) included different measures of mood and behaviour, such as depression, anxiety, alcohol use, coping and empowerment, and two included open-ended satisfaction questionnaires. ${ }^{26,27}$ Qualitative interviews of significant others were employed in one study. ${ }^{24}$

There were considerable differences in the data collection follow-up periods used in the studies. One of the randomised controlled trials collected data once, 12 months after completion of the intervention, and didn't record baseline measures. ${ }^{26}$ One study was a retrospective design so measures were only administered at programme completion. ${ }^{24}$ One study collected data at baseline and programme completion; ${ }^{25}$ one at baseline and three-months; ${ }^{27}$ and one at a minimum of four time points. ${ }^{22}$ 
No significant improvements in social activity level or social network size were found ${ }^{27}$ and there were no significant improvements in Craig Handicap Assessment and Reporting Technique social integration scores. ${ }^{22,} 27$ Minimal impacts were observed on enhancing social support from families, friends and the community. ${ }^{24}$ Significant improvements were found in community integration and independence. ${ }^{22}$ There was a trend towards increased satisfaction with social life in the past month ${ }^{27}$ and 30 of 57 traumatic brain injury participants successfully achieved goals of returning to employment or education..$^{22}$ Significant improvements of note were shown in measures of behavioural control; chaos in the living environment; alcohol use; emotion-focused coping; physical quality of life; ${ }^{26}$ perceived social support; ${ }^{27}$ depression; empowerment; coping; life satisfaction and communication with healthcare professionals. ${ }^{25}$ Significant increases in depression were also observed in one study. ${ }^{27} \mathrm{High}$ levels of satisfaction among both mentors and mentees were reported across all six studies and positive impacts observed on increasing knowledge of traumatic brain injury; overall quality of life; improving general outlook; and ability to cope with depression. ${ }^{24}$ Outcomes were not provided according to severity of injury. The results should be interpreted with caution due to the limitations of the studies. 
Each of the papers concluded that one-to-one peer mentoring showed promise as an intervention for traumatic brain injury survivors, gained high satisfaction ratings, and that further research was needed. It was recommended that future research should identify the most useful components of the intervention and that small sample sizes and limited 'dosage' of interactions were limitations that should be addressed in a future trial. ${ }^{26,27}$

\section{Discussion}

There is a lack of high-quality published evidence for the effectiveness of peer mentoring after traumatic brain injury. The evidence available comes from small-scale studies of limited quality conducted in the United States. The studies covered fairly brief intervention periods and provided limited information on long-term success or sustainability. Despite concerns about the quality of the studies and their generalisability, they produced some promising results and provided useful information regarding the conduct of peer mentoring research. Overall, the potential for peer mentoring to impact on social and leisure participation (among other outcomes), and the optimum design of an intervention, remain unclear. Further research is required to determine the efficacy of peer mentoring interventions for traumatic brain injury survivors. 
The heterogeneity of the studies, including designs, time scales and follow-up periods, makes it difficult to compare them and draw clear conclusions. Only two randomised controlled trials have been conducted and these were both of low quality in terms of randomisation procedure. ${ }^{26,27}$ One was a pilot study with just 12 mentored participants, ${ }^{27}$ while the larger trial compared mentored and control groups without recording baseline measures. ${ }^{26}$ Hibbard's 2002 study also did not take measures at baseline and relied on subjective self-reporting to assess the impact of the intervention. ${ }^{24}$ The mixture of neurological disabilities studied by Kolakowsky-Hayner et al mean that many of the results cannot be interpreted as applying specifically to people with traumatic brain injury. ${ }^{22}$ Also, one of the included studies was a conference abstract with minimal information on methodology 25 and another was a service description with no assessment of outcomes. ${ }^{23}$

Despite the limitations of the studies, the range of significant improvements on mood and lifestyle measures provides some evidence for their effectiveness. The results suggest that a peer mentor could help traumatic brain injury survivors to modify problem behaviour and employ healthier coping strategies. The impact of peer mentoring on social and leisure participation is uncertain, 
with only one study looking specifically at social peer mentoring and reporting mixed results. ${ }^{27}$ However, the significant increase in perceived social support, trend towards improved satisfaction with social life, gains in community integration and independence, and subjective reports of enhanced social support are all encouraging. $22,24,26,27$ Significantly more evidence would be required before firm conclusions can be drawn regarding any outcomes.

Unfortunately, there was little to be learned from the studies in terms of the content of mentoring sessions. It is not known whether discussions in sessions kept to the intended topics and or what activities took place. There was also considerable variation in the nature of the contacts (with most studies allowing in-person, telephone or email correspondence), the frequency of contacts and duration of partnerships. Consistent implementation of these variables is important in order to understand the factors, or 'active ingredients', which influenced outcomes.

Only one of the articles reports any level of detail regarding an underpinning theoretical framework to the study and this refers to participatory action research. ${ }^{24}$ Other theories which could be used to inform the development of peer mentoring for disability groups have been suggested by Hayes and 
Balcazar, such as the ecological principles of community psychology and the social-ecological model of disability. ${ }^{32}$ Similarly to participatory action research these ideas centre on thinking about disabled people as useful resources in their community, and on the importance of adapting a person's environment in order to reduce the impact of their disability. Other conceptual frameworks which could usefully inform mentoring programmes include socio-cognitive approaches, such as Bandura's self-efficacy theory, ${ }^{33}$ and theories of motivation and leadership, such as personal construct theory ${ }^{34}$ and transformational leadership theory ${ }^{35}$ (utilised by an ongoing, unpublished study in Wales of 'peer coaching' after stroke).

Despite the studies' methodological problems there is much to be learned from the mentor training programmes, assessments of logistical challenges and participant evaluations. ${ }^{22-24,26,27}$ It is important that future studies train mentors thoroughly and build on the training programmes described in the papers and published online. ${ }^{24,26,27}$ The logistical challenges described will also need to be considered and can potentially be avoided by careful planning of the intervention model. Finally, the positive feedback from the majority of participants indicated that the interventions were enjoyable and subjectively beneficial. 
It should be noted that one further study has recently been conducted in New Zealand from which a conference poster has been published reporting positive experiences of participants. ${ }^{36}$ This was identified in a recently updated literature search and the full data from the study has not yet been published.

The strength of this systematic review was the robust methodology. The search strategy was carefully designed and a large number of relevant databases were searched, while two reviewers independently conducted all screening, data extraction and quality assessment. Grey literature searches, hand-searching of reference lists, author citation searches and correspondence with authors also strengthened the study.

The specificity of the research question to traumatic brain injury could be considered a limitation of the review. Two published abstracts referring to an acquired brain injury $(\mathrm{ABI})$ peer mentoring study in Canada were excluded as they didn't contain information regarding traumatic brain injury survivors. ${ }^{37,}, 38 \mathrm{~A}$ case study which involved a traumatic brain injury survivor mentoring an encephalitis survivor was also excluded. ${ }^{39}$ As similar issues apply to people with all forms of brain injury it may be appropriate to widen the scope of a future review to include all $A B I$. 


\section{Clinical messages}

- Definitive evidence is lacking for the effectiveness of peer mentoring after traumatic brain injury

- The few studies conducted showed promising results

- The majority of studies have not described a theoretical framework

- The identified studies do not describe the content of sessions or identify the 'active ingredient' of peer mentoring

\section{Acknowledgements}

The authors would like to thank Jeanette Eldridge, information scientist at the University of Nottingham, for her help developing the search strategy for this review. 


\section{Competing interests and source of funding}

No competing interests declared. This study was funded by a grant from the Slater and Gordon Health Projects and Research fund managed by the London Community Foundation.

\section{Contributors}

RM developed the search strategy, performed all searches, removed duplicate records, screened all titles and abstracts and extracted data from the included full papers. RM was lead reviewer and lead author of this systematic review paper.

JFS is an experienced systematic reviewer and acted as mentor to RM throughout the design phase of the systematic review protocol. JFS was second reviewer, assisting RM with the screening of unduplicated titles and abstracts, and the data extraction and quality assessment of included studies. JFS coauthored this paper. 
$\mathrm{KR}$ devised the research question that this systematic review sought to address. KR acted as third reviewer in cases of uncertainty over the inclusion or exclusion of studies. KR co-authored this paper and had overall responsibility for the successful completion of the systematic review.

\section{References}

1. Headway - the brain injury association. 2016. Available from:

https://www.headway.org.uk/about-brain-injury/individuals/types-of-brain-injury/. 2. Hassan Z, Smith M, Littlewood S, Bouamra O, Hughes D, Biggin C, et al. Head injuries: a study evaluating the impact of the NICE head injury guidelines. Emergency medicine journal 2005; 22 (12): 845-9.

3. Headway - the brain injury association \& Health and Social Care Information Centre. 2016.

4. Hyder AA, Wunderlich CA, Puvanachandra P, Gururaj G, Kobusingye OC. The impact of traumatic brain injuries: a global perspective. NeuroRehabilitation-An Interdisciplinary Journal 2007; 22 (5): 341-54.

5. Andelic N, Hammergren N, Bautz-Holter E, Sveen U, Brunborg C, Røe C. Functional outcome and health-related quality of life 10 years after moderate-to-severe traumatic brain injury. Acta Neurologica Scandinavica 2009; 120 (1): 16-23.

6. Sendroy-Terrill M, Whiteneck GG, Brooks CA. Aging with traumatic brain injury: cross-sectional follow-up of people receiving inpatient rehabilitation over more than 3 decades. Archives of physical medicine and rehabilitation 2010; 91 (3): 489-97.

7. Williams WH, Potter S, Ryland $\mathrm{H}$. Mild traumatic brain injury and postconcussion syndrome: a neuropsychological perspective. Journal of Neurology, Neurosurgery \& Psychiatry 2010: jnnp. 2008.171298.

8. Theadom A, Parag V, Dowell T, McPherson K, Starkey N, Barker-Collo S, et al. Persistent problems 1 year after mild traumatic brain injury: a longitudinal population study in New Zealand. Br J Gen Pract 2016; 66 (642): e16-e23.

9. Hou R, Moss-Morris R, Peveler R, Mogg K, Bradley BP, Belli A. When a minor head injury results in enduring symptoms: a prospective investigation of risk factors for 
postconcussional syndrome after mild traumatic brain injury. Journal of Neurology, Neurosurgery \& Psychiatry 2011: jnnp-2011-300767.

10. Seltzer M, Bier D. The Power of Peer Mentoring: Waisman Center; University of Wisconsin-Madison; 2006.

11. Secomb J. A systematic review of peer teaching and learning in clinical education. Journal of clinical nursing 2008; 17 (6): 703-16.

12. Allen TD, Eby LT, Poteet ML, Lentz E, Lima L. Career benefits associated with mentoring for proteges: a meta-analysis. Journal of applied psychology 2004; 89 (1): 127.

13. Spencer R, Liang B. "She gives me a break from the world": Formal youth mentoring relationships between adolescent girls and adult women. The Journal of Primary Prevention 2009; 30 (2): 109-30.

14. Boschen KA, Tonack M, Gargaro J. Long-term adjustment and community reintegration following spinal cord injury. International Journal of Rehabilitation Research 2003; 26 (3): 157-64.

15. Young JM, Lawrence W, Quick P, editors. A unique role: the peer mentor on the spinal cord team at GF Strong Rehab Centre. Healthcare Management Forum; 1999: Elsevier.

16. Kelly EH. Community competence and violently acquired spinal cord injury: Employment as a peer role model. Rehabilitation Psychology 2007; 52 (2): 226.

17. Ljungberg I, Kroll T, Libin A, Gordon S. Using peer mentoring for people with spinal cord injury to enhance self-efficacy beliefs and prevent medical complications. Journal of clinical nursing 2011; 20 (3-4): 351-8.

18. De Vinney DJ. The Effects of Peer-mentoring on the Social Participation and Psychological Adjustment of Individuals with Spinal Cord Injury: University of Wisconsin--Madison; 2000.

19. Moher D, Liberati A, Tetzlaff J, Altman DG. Preferred reporting items for systematic reviews and meta-analyses: the PRISMA statement. Annals of internal medicine 2009; 151 (4): 264-9.

20. Morris R, Fletcher-Smith J, Radford K. A systematic review of peer mentoring interventions for people with traumatic brain injury. PROSPERO 2015;

CRD42015025626: Available from

http://www.crd.york.ac.uk/PROSPERO/display record.asp?ID=CRD42015025626.

21. Pluye P, Robert E, Cargo M, Bartlett G, O'Cathain A, Griffiths F, et al. Proposal: A mixed methods appraisal tool for systematic mixed studies reviews. Montréal: McGill University 2011: 1-8.

22. Kolakowsky-Hayner S, Wright J, Shem K, Medel R, Duong T. An effective community-based mentoring program for return to work and school after brain and spinal cord injury. NeuroRehabilitation 2012; 31 (1): 63-73.

23. Moreci G. A model system of traumatic brain injury peer support importance, development and process. NeuroRehabilitation 1996; 7 (3): 211-8.

24. Hibbard M, Cantor J, Charatz H, Rosenthal R, Ashman T, Gundersen N, et al. Peer support in the community: initial findings of a mentoring program for individuals 
with traumatic brain injury and their families. J Head Trauma Rehabil 2002; 17 (2): 11231.

25. Hibbard M, Cantor J. Evaluating the impact of a peer mentoring program for individuals with TBI and their families. Neurorehabilitation \& Neural Repair 2005; 19 (4): 388-9.

26. Hanks R, Rapport L, Wertheimer J, Koviak C. Randomized controlled trial of peer mentoring for individuals with traumatic brain injury and their significant others. Archives of Physical Medicine and Rehabilitation 2012; 93 (8): 1297-304.

27. Struchen MA, Davis LC, Bogaards JA, Hudler-Hull T, Clark AN, Mazzei DM, et al. Making connections after brain injury: development and evaluation of a social peermentoring program for persons with traumatic brain injury. J Head Trauma Rehabil $2011 ; 26$ (1): 4-19.

28. Santelli B, Singer GH, DiVenere N, Ginsberg C, Powers LE. Participatory action research: Reflections on critical incidents in a PAR project. Research and Practice for Persons with Severe Disabilities 1998; 23 (3): 211-22.

29. Cornwall A, Jewkes R. What is participatory research? Social science \& medicine 1995; 41 (12): 1667-76.

30. Mellick D. The craig handicap assessment and reporting technique-short form. The Center for Outcome Measurement in Brain Injury 2000: 298-305.

31. Diener E, Emmons RA, Larsen RJ, Griffin S. The satisfaction with life scale. Journal of personality assessment 1985; 49 (1): 71-5.

32. Hayes E, Balcazar F. Peer-mentoring and disability: current applications and future directions. In: Keel MI, editor. Mentoring: Program Development, Relationships and Outcomes 2009. p. 123-41.

33. Bandura A. Self-efficacy: toward a unifying theory of behavioral change. Psychological review 1977; 84 (2): 191.

34. Kelly GA. A brief introduction to personal construct theory. New York: John Wiley \& Sons Ltd.; 2003.

35. Bass BM. Leadership and performance beyond expectations: Free Press; Collier Macmillan; 1985.

36. Kersten P, Kayes NM, Cummins C, Siegert RJ, Elder H, Weatherall M, et al. Peer mentoring after traumatic brain injury (TBI)-a valuable experience for mentees and mentors. Archives of Physical Medicine and Rehabilitation 2015; 96 (10): e87.

37. Boschen KA. Evaluation of an ontario $A B I$ peer support mentoring program. Archives of Physical Medicine and Rehabilitation 2012; 93 (10): E28-E9.

38. Gargaro J, Boschen K. Peer support mentoring programs after brain injury: Do they make a difference? Brain Inj 2012; 26 (4-5): 739-40.

39. Fraas $\mathrm{M}$, Bellerose A. Mentoring programme for adolescent survivors of acquired brain injury. Brain Inj 2010; 24 (1): 50-61. 


\section{Appendix one - search strategy for selected databases}

Database: Ovid MEDLINE 1946 to September week 12016 (adapted for other databases hosted on Ovid)

1 exp Brain injuries/ OR exp craniocerebral trauma/ OR exp intracranial hemorrhage/ OR exp Brain Concussion/ OR brain injury.mp. OR brain injuries.mp. OR head injury.mp. OR head injuries.mp. OR traumatic brain injury.mp. OR traumatic brain injuries.mp. OR head trauma.mp. OR craniocerebral trauma.mp. OR brain trauma.mp. OR acquired brain injury.mp. OR acquired brain injuries.mp. OR diffuse axonal injury.mp. OR diffuse axonal injuries.mp. OR concussion.mp. OR brain damage.mp. OR subarachnoid haemorrhage.mp. OR subarachnoid hemorrhage.mp.

2 peer support.mp. or mentor.mp. or mentoring.mp. or mentors.mp. or mentorship.mp. or peer coach.mp. or peer coaching.mp. or peer coaches.mp. or peer counselling.mp. or peer counsellor.mp. or peer counsellors.mp. or peer counseling.mp. or peer counselor.mp. or peer counselors.mp. or peer partner.mp. or peer partners.mp. or peer partnering.mp. or peer tutor.mp. or peer tutors.mp. or peer tutoring.mp. or peer trainer.mp. or peer training.mp. or peer trainers.mp. or peer education.mp. or peer educator.mp. or peer educators.mp. or peer teacher.mp. or peer teachers.mp. or peer teaching.mp.

31 AND 2

Database: CINAHL with Full Text (EBSCOHost) 1981 - September 212016

1. (MH "head injuries+")

2. (MH "brain injuries + )

3. (MH "brain concussion+")

4. (MH "intracranial hemorrhage+)

5. (MH "brain damage, chronic+")

6. (MH "cerebral hemorrhage+")

7. TX brain injury

8. TX brain injuries

9. TX head injury

10. TX head injuries 
11. TX head trauma

12. TX brain trauma

13. TX diffuse axonal injury

14. TX brain damage

15. TX concussion

16. TX subarachnoid haemorrhage

17. TX subarachnoid hemorrhage

18. 1 OR 2 OR 3 OR 4 OR 5 OR 6 OR 7 OR 8 OR 9 OR 10 OR 11 OR 12 OR 13 OR 14 OR 15 OR 16 OR 17

19. TI Peer support OR mentor OR mentoring OR mentors OR mentorship OR peer coach OR peer coaching OR peer coaches OR peer counselling OR peer counsellor or peer counsellors OR peer counseling OR peer counselor or peer counselors or peer partner or peer partners or peer partnering or peer tutor or peer tutors OR peer tutoring OR peer trainer OR peer training OR peer trainers OR peer education OR peer educator OR peer educators OR peer teacher OR peer teachers OR peer teaching

20. AB Peer support OR mentor OR mentoring OR mentors OR mentorship OR peer coach OR peer coaching OR peer coaches OR peer counselling OR peer counsellor or peer counsellors OR peer counseling OR peer counselor or peer counselors OR peer partner OR peer partners OR peer partnering OR peer tutor OR peer tutors OR peer tutoring OR peer trainer OR peer training OR peer trainers OR peer education OR peer educator OR peer educators OR peer teacher OR peer teachers OR peer teaching

21.SU Peer support OR mentor OR mentoring OR mentors OR mentorship OR peer coach OR peer coaching OR peer coaches OR peer counselling OR peer counsellor or peer counsellors OR peer counseling OR peer counselor or peer counselors OR peer partner OR peer partners OR peer partnering OR peer tutor OR peer tutors OR peer tutoring OR peer trainer OR peer training OR peer trainers OR peer education OR peer educator OR peer educators OR peer teacher OR peer teachers OR peer teaching

22. 19 OR 20 OR 21

23. 18 AND 22 


\section{Appendix two - Excluded papers and reasons for exclusion}

\begin{tabular}{|c|c|c|}
\hline Number & Study ID & Reason for exclusion \\
\hline 1 & $\begin{array}{l}\text { Abbot N, Wilkinson, L. School re-entry of } \\
\text { the brain injured student: A case study of } \\
\text { peer inservicing. Intervention in School } \\
\text { and Clinic 1992; } 27 \text { (4): 242-49. }\end{array}$ & $\begin{array}{l}\text { Incomplete version and insufficient } \\
\text { information. }\end{array}$ \\
\hline 2 & $\begin{array}{l}\text { Backhaus S, Ibarra S, Parrot D, Malec } \\
\text { J. Comparison of a cognitive behavioural } \\
\text { coping skills group to a peer support } \\
\text { group in improving self-efficacy and } \\
\text { neurobehavioural functions after brain } \\
\text { injury. Brain Injury } 2014 ; 28(5-6): 594 .\end{array}$ & Does not involve peer mentoring. \\
\hline 3 & $\begin{array}{l}\text { Balfanz-Vertiz K, Taylor K. Increasing } \\
\text { health and wellness through peer mentor } \\
\text { support. Journal of Head Trauma } \\
\text { Rehabilitation 2010; } 25 \text { (5): 384-85. }\end{array}$ & $\begin{array}{l}\text { Conference abstract with insufficient } \\
\text { information. No information about } \\
\text { traumatic brain injury participants. } \\
\text { Attempted several times to contact } \\
\text { the author but with no response. }\end{array}$ \\
\hline 4 & $\begin{array}{l}\text { Bates A, Cahill S, Fawdry T. Peer } \\
\text { support programs improve the } \\
\text { psychosocial functioning of those with } \\
\text { brain injury. Brain Impairment } 2013 ; 14 \\
(1): 179 \text {. }\end{array}$ & $\begin{array}{l}\text { Group support rather than any formal } \\
\text { peer mentoring. }\end{array}$ \\
\hline 5 & $\begin{array}{l}\text { Boschen K. Evaluation of an Ontario ABI } \\
\text { peer support mentoring program. } \\
\text { Archives of Physical Medicine and } \\
\text { Rehabilitation 2012; } 93 \text { (10): E28-E29. }\end{array}$ & $\begin{array}{l}\text { Conference abstract with insufficient } \\
\text { information to identify traumatic brain } \\
\text { injury participants. Contact with } \\
\text { author gleaned information relevant } \\
\text { to study but results unpublished and } \\
\text { unsuitable for assessment within this } \\
\text { systematic review. }\end{array}$ \\
\hline 6 & $\begin{array}{l}\text { Carr S, Schwarb A. The use of } \\
\text { volunteers within a comprehensive brain } \\
\text { injury day treatment program. Journal of } \\
\text { Head Trauma Rehabilitation } 2011 ; 26 \\
\text { (5): } 417 \text {. }\end{array}$ & $\begin{array}{l}\text { Conference abstract with insufficient } \\
\text { information regarding traumatic brain } \\
\text { injury participants and outcomes. } \\
\text { Unable to contact authors for further } \\
\text { information. }\end{array}$ \\
\hline 7 & $\begin{array}{l}\text { Easton A. Climb every mountain - a } \\
\text { road to recovery. Brain Impairment 2012; } \\
13(1): 177 .\end{array}$ & $\begin{array}{l}\text { Peer support/group trip rather than } \\
\text { peer mentoring. }\end{array}$ \\
\hline 8 & $\begin{array}{l}\text { Fleming J, Kuipers P, Foster M, Smith S, } \\
\text { Doig E. Evaluation of an outpatient, peer } \\
\text { group intervention for people with } \\
\text { acquired brain injury based on the ICF } \\
\text { 'Environment' dimension. Disability and } \\
\text { Rehabilitation 2009; } 31 \text { (20): 1666-75. }\end{array}$ & $\begin{array}{l}\text { Group intervention rather than one- } \\
\text { to-one peer mentoring. }\end{array}$ \\
\hline 9 & $\begin{array}{l}\text { Fraas } \mathrm{M} \text {, Bellerose, } \mathrm{A} \text {. Mentoring } \\
\text { programme for adolescent survivors of }\end{array}$ & $\begin{array}{l}\text { Only the mentor had traumatic brain } \\
\text { injury, not the mentored participant. }\end{array}$ \\
\hline
\end{tabular}




\begin{tabular}{|c|c|c|}
\hline & $\begin{array}{l}\text { acquired brain injury. Brain Injury 2010; } \\
24 \text { (1): } 50-61 \text {. }\end{array}$ & \\
\hline 10 & $\begin{array}{l}\text { Gargaro J, Boschen K. Peer support } \\
\text { mentoring programs after brain injury: } \\
\text { Do they make a difference? Brain Injury } \\
2012 ; 26 \text { (4-5): } 739-740 .\end{array}$ & $\begin{array}{l}\text { Conference abstract with no } \\
\text { information regarding participants } \\
\text { with traumatic brain injury. From the } \\
\text { same study as Boschen } 2012 \\
\text { abstract. }\end{array}$ \\
\hline 11 & $\begin{array}{l}\text { Haarbauer-Krupa J, Meulenbroek P, } \\
\text { Gibbs J, Turkstra L. The BRAIN } \\
\text { program: A model transition to adult lives } \\
\text { for teens with acquired brain injury. } \\
\text { Journal of Head Trauma Rehabilitation } \\
\text { 2010; } 25 \text { (5): 396-97. }\end{array}$ & $\begin{array}{l}\text { Conference abstract regarding } \\
\text { guideline development with no } \\
\text { information about peer mentoring. }\end{array}$ \\
\hline 12 & $\begin{array}{l}\text { Haarbauer-Krupa J. Readiness for } \\
\text { independence: Facilitation of the } \\
\text { transition to adulthood for teens with } \\
\text { ABI. Journal of Head Trauma } \\
\text { Rehabilitation } 2011 ; 26 \text { (5): } 433 \text {. }\end{array}$ & $\begin{array}{l}\text { Conference abstract with limited } \\
\text { information. Refers to 'peer coaches' } \\
\text { and author was contacted for further } \\
\text { information. The coaches were } \\
\text { college students although some self- } \\
\text { identified as having traumatic brain } \\
\text { injury. No traumatic brain injury } \\
\text { specific data has been collected. }\end{array}$ \\
\hline 13 & $\begin{array}{l}\text { Haarbauer-Krupa J, Vova J, Dyke J. A } \\
\text { comprehensive model transition program } \\
\text { for adolescents with acquired brain } \\
\text { injuries. Brain Injury 2012; } 26 \text { (4-5): 575- } \\
76 \text {. }\end{array}$ & $\begin{array}{l}\text { Conference abstract reporting same } \\
\text { study as Haarbauer-Krupa } 2011 \\
\text { above. }\end{array}$ \\
\hline 14 & $\begin{array}{l}\text { Johnson K, Davis P. A supported } \\
\text { relationships intervention to increase the } \\
\text { social integration of persons with } \\
\text { traumatic brain injuries. Behaviour } \\
\text { Modification } 1998 ; 22(4): 502-28 \text {. }\end{array}$ & Mentors had no disability. \\
\hline 15 & $\begin{array}{l}\text { Kennedy A, Turner B, Kendall M. Growth } \\
\text { in a 'New World': Case studies of peer } \\
\text { leader experiences in the STEPS } \\
\text { program for people with acquired brain } \\
\text { injury. Brain Impairment 2011; } 12 \text { (2): } \\
152-64 \text {. }\end{array}$ & $\begin{array}{l}\text { Intervention consisted of groups led } \\
\text { by peer leaders and staff leaders. } \\
\text { Not one-to-one peer mentoring. }\end{array}$ \\
\hline 16 & $\begin{array}{l}\text { Kersten P., Kayes N., Cummins C., } \\
\text { Siegert R., Elder H., Weatherall M., } \\
\text { Seemann R., Foster A., Babbage D. \& } \\
\text { McPherson K. Peer mentoring after } \\
\text { traumatic brain injury (TBI) - a valuable } \\
\text { experience for mentees and mentors. } \\
\text { Archives of Physical Medicine and } \\
\text { Rehabilitation 2015; } 96 \text { (10): e87. }\end{array}$ & $\begin{array}{l}\text { Brief conference abstract of study } \\
\text { not yet fully analysed and published. }\end{array}$ \\
\hline 17 & $\begin{array}{l}\text { MacEachen E, Kosny A, Ferrier S. } \\
\text { Unexpected barriers in return to work: } \\
\text { Lessons learned from injured worker }\end{array}$ & $\begin{array}{l}\text { This was for any type of injury } \\
\text { preventing return to the place of }\end{array}$ \\
\hline
\end{tabular}




\begin{tabular}{|c|c|c|}
\hline & $\begin{array}{l}\text { peer support groups. Work } 2007 ; 29 \text { (2): } \\
155-64 \text {. }\end{array}$ & $\begin{array}{l}\text { employment. It used peer support } \\
\text { rather than mentoring. }\end{array}$ \\
\hline 18 & $\begin{array}{l}\text { McLean A, Jarus T. The brain injury } \\
\text { drop-in centre: An innovative program } \\
\text { addressing social participation and } \\
\text { quality of life. Brain Injury 2010; } 24 \text { (3): } \\
226 \text {. }\end{array}$ & $\begin{array}{l}\text { The intervention is a drop-in centre } \\
\text { for people with traumatic brain injury. } \\
\text { Not specifically a peer mentoring } \\
\text { intervention. }\end{array}$ \\
\hline 19 & $\begin{array}{l}\text { Rowden-Racette K. } 2009 \text { Mentoring } \\
\text { program relieves staffing shortages. } \\
\text { ASHA Leader 2009; } 14(11): 26 \text {. }\end{array}$ & $\begin{array}{l}\text { This is a staff mentoring program not } \\
\text { a brain injury peer mentoring } \\
\text { program. }\end{array}$ \\
\hline 20 & $\begin{array}{l}\text { Schultz C. Helping factors in a peer- } \\
\text { developed support group for persons } \\
\text { with head injury, Part 2: Survivor } \\
\text { interview perspective. American Journal } \\
\text { of Occupational Therapy 1994; } 48 \text { (4): } \\
\text { 305-09. }\end{array}$ & $\begin{array}{l}\text { Support group rather than peer } \\
\text { mentoring. }\end{array}$ \\
\hline 21 & $\begin{array}{l}\text { Schwartzberg S. Helping factors in a } \\
\text { peer-developed support group for } \\
\text { persons with head injury, Part 1: } \\
\text { Participant observer perspective. } \\
\text { American Journal of Occupational } \\
\text { therapy } 1994 ; 48 \text { (4): } 297-304 .\end{array}$ & $\begin{array}{l}\text { Support group rather than peer } \\
\text { mentoring. }\end{array}$ \\
\hline 22 & $\begin{array}{l}\text { Struchen M, Davis L, Clark A, Mazzei D, } \\
\text { Boggards J, Sander A. Design and } \\
\text { implementation of a social peer } \\
\text { mentoring program for persons with } \\
\text { traumatic brain injury. Archives of } \\
\text { Physical Medicine and Rehabilitation } \\
\text { 2010; } 91 \text { (10): e10-e11. }\end{array}$ & $\begin{array}{l}\text { Brief conference abstract reporting } \\
\text { the same data as a full paper } \\
\text { included in final selection. }\end{array}$ \\
\hline 23 & $\begin{array}{l}\text { Sulewski J, Kugler R, Kramer J. } \\
\text { Spreading a positive message about } \\
\text { work, earnings and benefits through peer } \\
\text { networking: Findings from the Peer } \\
\text { Employment Benefits Network. Journal } \\
\text { of Vocational Rehabilitation } 2010 ; 32 \text { (3): } \\
151-161 \text {. }\end{array}$ & $\begin{array}{l}\text { No brain injury specific information } \\
\text { provided. }\end{array}$ \\
\hline 24 & $\begin{array}{l}\text { Tate R, Wakim D, Genders M. A } \\
\text { systematic review of the efficacy of } \\
\text { community-based leisure/social activity } \\
\text { programmes for people with traumatic } \\
\text { brain injury. Brain Impairment } 2014 ; 15 \\
\text { (3): } 157-76 \text {. }\end{array}$ & $\begin{array}{l}\text { Systematic review of social and } \\
\text { leisure programmes which includes } \\
\text { Struchen study. }\end{array}$ \\
\hline 25 & $\begin{array}{l}\text { Tennille T, Leisa E. Does social isolation } \\
\text { improve for Vietnamese people with } \\
\text { brain injury (BI) when they participate in } \\
\text { client led culturally sensitive peer } \\
\text { groups. Brain Impairment 2013; } 14 \text { (1): } \\
209 \text {. }\end{array}$ & $\begin{array}{l}\text { Appears to be a group intervention } \\
\text { rather than peer mentoring and no } \\
\text { further information could be obtained } \\
\text { from the author. }\end{array}$ \\
\hline
\end{tabular}




\begin{tabular}{|c|c|c|}
\hline 26 & $\begin{array}{l}\text { Turner B, Kennedy A, Kendall M, } \\
\text { Muenchberger H. Supporting the growth } \\
\text { of peer-professional workforces in } \\
\text { healthcare settings: an evaluation of a } \\
\text { targeted training approach for volunteer } \\
\text { leaders of the STEPS Program. } \\
\text { Disability and Rehabilitation } 2014 ; 36 \\
\text { (14): } 1219-26 \text {. }\end{array}$ & $\begin{array}{l}\text { Training evaluation. Intervention } \\
\text { consisted of groups led by peer } \\
\text { leaders and staff leaders. Not one- } \\
\text { to-one peer mentoring. }\end{array}$ \\
\hline 27 & $\begin{array}{l}\text { Williams R, Bambara J, Turner A. A } \\
\text { scoping study of one-to-one peer } \\
\text { mentorship interventions and } \\
\text { recommendations for application with } \\
\text { veterans with postdeployment syndrome. } \\
\text { Journal of Head Trauma Rehabilitation } \\
2012 ; 27 \text { (4): 261-273. }\end{array}$ & $\begin{array}{l}\text { Scoping review which cites Struchen } \\
\text { and Hibbard and looks at peer } \\
\text { mentoring in a range of populations. }\end{array}$ \\
\hline 28 & $\begin{array}{l}\text { Wiseman-Hakes C, Stewart M, } \\
\text { Wasserman R, Schuller R. Peer group } \\
\text { training of pragmatic skills in adolescents } \\
\text { with acquired brain injury. Journal of } \\
\text { Head Trauma Rehabilitation } 1998 ; 13 \\
\text { (6): } 23-38 \text {. }\end{array}$ & $\begin{array}{l}\text { Group training rather than a peer } \\
\text { mentoring intervention. }\end{array}$ \\
\hline 29 & $\begin{array}{l}\text { Wonders J. "My Life Now" - The } \\
\text { "reciprocity" of peer support for life long } \\
\text { living. Journal of Head Trauma } \\
\text { Rehabilitation 2008; } 23 \text { (5): } 351 \text {. }\end{array}$ & $\begin{array}{l}\text { Peer support and presentations to } \\
\text { group rather than any form of peer } \\
\text { mentoring. }\end{array}$ \\
\hline 30 & $\begin{array}{l}\text { Zelikovsky N, Petrongolo J. Utilizing peer } \\
\text { mentors for adolescents with chronic } \\
\text { health conditions: Potential benefits and } \\
\text { complications. Pediatric Transplantation } \\
2013 ; 17 \text { (7): 589-591. }\end{array}$ & No connection to brain injury. \\
\hline
\end{tabular}




\section{Appendix three - Study design and participant characteristics of studies identified in systematic review}

Information in this table is adapted from the text of the papers, along with comments on missing information where relevant. Extended direct quotes from the papers are italicised and in quotation marks.

\begin{tabular}{|c|c|c|c|c|c|c|}
\hline Study & $\begin{array}{l}\text { Kolakowsky-Hayner et } \\
\text { al } 2012 \text { (reference no. } \\
\text { 22) }\end{array}$ & $\begin{array}{l}\text { Moreci } 1996 \text { (reference } \\
\text { no. 23) }\end{array}$ & $\begin{array}{l}\text { Hibbard et al 2002 } \\
\text { (reference no. 24) }\end{array}$ & $\begin{array}{l}\text { Hibbard and Cantor } \\
2005 \text { (reference no. 25) }\end{array}$ & $\begin{array}{l}\text { Hanks et al } 2012 \\
\text { (reference no. 26) }\end{array}$ & $\begin{array}{l}\text { Struchen et al 2011 } \\
\text { (reference no. 27) }\end{array}$ \\
\hline Design & $\begin{array}{l}\text { Before and after study } \\
\text { - non-randomised. }\end{array}$ & Description of service. & $\begin{array}{l}\text { Pilot concurrent mixed } \\
\text { methods design. }\end{array}$ & Quasi-experimental. & $\begin{array}{l}\text { Single site Randomised } \\
\text { Controlled Trial. }\end{array}$ & $\begin{array}{l}\text { Pilot randomised } \\
\text { controlled trial. }\end{array}$ \\
\hline Context/setting & $\begin{array}{l}\text { San Jose, USA. } \\
\text { Community. }\end{array}$ & $\begin{array}{l}\text { San Jose, USA. } \\
\text { Rehabilitation unit for } \\
\text { visits and community } \\
\text { for phone calls. }\end{array}$ & $\begin{array}{l}\text { New York, USA. } \\
\text { Community. }\end{array}$ & $\begin{array}{l}\text { New York, USA. } \\
\text { Community. }\end{array}$ & $\begin{array}{l}\text { Detroit, USA. } \\
\text { Community. }\end{array}$ & $\begin{array}{l}\text { Houston, USA. } \\
\text { Community. }\end{array}$ \\
\hline $\begin{array}{l}\text { Participant } \\
\text { recruitment (mentors } \\
\text { and mentees) }\end{array}$ & No details. & $\begin{array}{l}\text { Social services referred } \\
\text { patients on rehab unit } \\
\text { and their families. } \\
\text { No details of mentor } \\
\text { recruitment. }\end{array}$ & $\begin{array}{l}\text { Programme ppts } \\
\text { recruited through } \\
\text { website, outreach } \\
\text { coordinators, } \\
\text { independent living } \\
\text { centres, rehabilitation } \\
\text { hospitals, support } \\
\text { groups and } \\
\text { conferences. The first } \\
52 \text { partners to enrol in } \\
\text { the TBI-Mentoring } \\
\text { Partnership } \\
\text { Programme who had } \\
\text { completed their } \\
\text { partnerships were } \\
\text { invited to participate in } \\
\text { the research project. }\end{array}$ & No details. & $\begin{array}{l}\text { TBI survivors (and their } \\
\text { significant others) who } \\
\text { were enrolled in the } \\
\text { South Eastern } \\
\text { Michigan TBI System } \\
\text { were approached } \\
\text { individually. Mentors } \\
\text { were hired as } \\
\text { contingent employees } \\
\text { in order to maximise } \\
\text { engagement. No other } \\
\text { details of how mentors } \\
\text { were recruited or where } \\
\text { from. }\end{array}$ & $\begin{array}{l}\text { Recruited through } \\
\text { outpatient clinics at } 2 \\
\text { rehabilitation hospitals, } \\
\text { via in-person, written } \\
\text { and online methods. } \\
\text { Potential participants } \\
\text { were informed that they } \\
\text { may be either a mentor } \\
\text { or peer partner. }\end{array}$ \\
\hline $\begin{array}{l}\text { Participant numbers } \\
\text { and demographics }\end{array}$ & $\begin{array}{l}\text { Mentees: Aged } \\
\text { between } 16 \text { and } 26.89 \\
\text { mentees successfully } \\
\text { matched and } \\
\text { participated through to } \\
\text { completion of the } \\
\text { programme of which } 57\end{array}$ & Mentees: Not stated. & $\begin{array}{l}\text { Mentees: } 20 ; 11 \mathrm{TBI} \\
\text { and } 9 \text { family members. } \\
\text { Male = } 6 \text {, Female = } 14 \text {; } \\
\text { African-American (4), } \\
\text { White, (14), other (2). } \\
\text { Age: }<19(1) ; 19-30(1) \text {; } \\
31-45(12)>46(6) \text {. }\end{array}$ & $\begin{array}{l}\text { Mentees: Intervention } \\
\text { group; } 64 \text { individuals } \\
\text { with TBI and } 30 \text { family } \\
\text { members: Control } \\
\text { group; } 30 \text { individuals } \\
\text { with TBI and } 10 \text { family } \\
\text { members. }\end{array}$ & $\begin{array}{l}\text { Mentees: People with } \\
\text { TBI }(n=96) \text { and } \\
\text { significant } \\
\text { others/caregivers } \\
(n=62) .47 \text { TBI } \\
\text { mentees, } 49 \text { TBI } \\
\text { control group members, }\end{array}$ & $\begin{array}{l}\text { Mentees: } \mathrm{N}=30 ; \\
\text { mentoring condition - } \\
12 ; \text { control condition - } \\
\text { 18. Age, mean [min- } \\
\text { max] - } 31.7 \text { [21-68]. } \\
\text { Gender - Male - 24. } \\
\text { White - 14; Black - 7; }\end{array}$ \\
\hline
\end{tabular}




\begin{tabular}{|c|c|c|c|c|c|c|}
\hline & $\begin{array}{l}\text { had TBI. } 12 \text { were still } \\
\text { engaged in mentoring } \\
\text { at conclusion of } \\
\text { programme and were } \\
\text { excluded from analysis. } \\
77 \text { were included in the } \\
\text { analysis. } \\
\text { Demographic details of } \\
\text { participants are } \\
\text { provided but not for TBI } \\
\text { participants. } \\
\text { Mentors: } N=121(29 \% \\
\text { with TBI). }\end{array}$ & & $\begin{array}{l}\text { Mentors: Provided for } \\
\text { programme as a whole } \\
\text { but not for mentors of } \\
\text { study participants. } \\
\text { To determine whether } \\
\text { the sample of partners } \\
\text { who participated was } \\
\text { representative of the } \\
\text { larger pool of partners, } \\
\text { chi square statistics } \\
\text { and } t \text { tests were } \\
\text { computed on select } \\
\text { demographic variables } \\
\text { comparing study } \\
\text { participants with } \\
\text { partners who } \\
\text { declined the interview. } \\
\text { No significant } \\
\text { differences between } \\
\text { the two subgroups } \\
\text { were found. }\end{array}$ & Mentors: Not stated. & 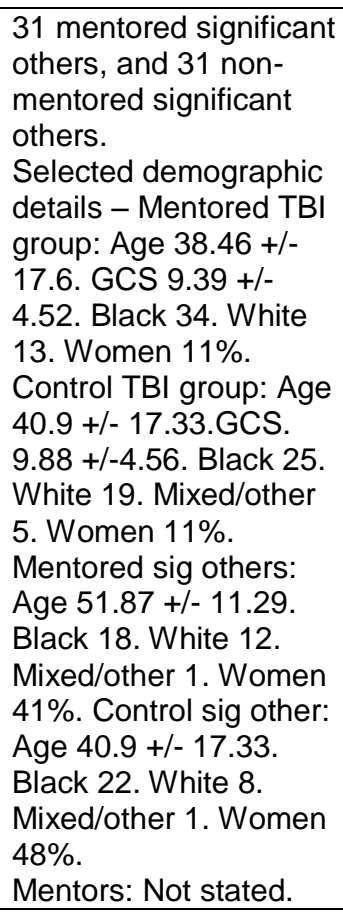 & $\begin{array}{l}\text { Hispanic - 8; Other - } 1 \\
\text {.Injury severity: Mild - } \\
6 \text {; Severe }-22 \text { (2 } \\
\text { missing). } \\
\text { Mentors: } N=11 . \text { Age, } \\
\text { mean [min-max] - 36.3 } \\
\text { [24-62]: Gender; Male - } \\
\text { 7. Ethnicity: White - 9; } \\
\text { Black - } 1 \text {; Hispanic - } 1 \text {. } \\
\text { Injury severity: } \\
\text { Moderate }-1(11.1 \%) ; \\
\text { Severe }-8(88.9 \%)\end{array}$ \\
\hline Mentor eligibility & $\begin{array}{l}\text { Minimum } 2 \text { years post } \\
\text { injury and with a high } \\
\text { level of acceptance and } \\
\text { successful integration } \\
\text { into community (e.g., } \\
\text { working or post- } \\
\text { secondary education). }\end{array}$ & $\begin{array}{l}\text { Experience with TBI, } \\
\text { positive references and } \\
\text { personal attributes } \\
\text { such as genuineness, } \\
\text { ability to listen, } \\
\text { appropriate empathy } \\
\text { and a positive regard } \\
\text { for people. }\end{array}$ & $\begin{array}{l}\text { Willingness to volunteer } \\
\text { necessary time; } \\
\text { successful personal } \\
\text { adjustment to TBI; } \\
\text { insight into limitations } \\
\text { and strengths; absence } \\
\text { of psychiatric problems; } \\
\text { ability to listen and } \\
\text { empathize; ability to } \\
\text { inhibit personal } \\
\text { responses when } \\
\text { necessary. }\end{array}$ & No details. & $\begin{array}{l}\text { Evaluated on social } \\
\text { competency, } \\
\text { willingness to talk } \\
\text { openly about disability } \\
\text { and life experiences, } \\
\text { motivation, and } \\
\text { commitment to } \\
\text { participation. }\end{array}$ & $\begin{array}{l}\text { Medically documented } \\
\text { TBI and community- } \\
\text { dwelling; >18; not in a } \\
\text { rehab program; criminal } \\
\text { background check; } \\
\text { references; minimum } \\
\text { Social Integration } \\
\text { subscale score of } 100 \\
\text { on CHART-SF. }\end{array}$ \\
\hline
\end{tabular}




\begin{tabular}{|c|c|c|c|c|c|c|}
\hline Mentee eligibility & $\begin{array}{l}\text { Individuals with TBI, } \\
\mathrm{SCl} \text { and other } \\
\text { neurological conditions } \\
\text { between the ages of } 16 \\
\text { and } 26 .\end{array}$ & No details. & $\begin{array}{l}\text { Excluded if; risk of } \\
\text { suicidal or violent } \\
\text { behaviour; had } \\
\text { psychiatric/substance } \\
\text { abuse problems; } \\
\text { Inability to articulate } \\
\text { reasons for wanting } \\
\text { peer support; no } \\
\text { personal interest in } \\
\text { receiving peer support; } \\
\text { excessive negativity, } \\
\text { anger/volatility; severe } \\
\text { cognitive impairments; } \\
\text { no awareness of brain } \\
\text { injury effects; no desire } \\
\text { to change life situation. }\end{array}$ & $\begin{array}{l}\text { Individuals with TBI and } \\
\text { their family members. }\end{array}$ & $\begin{array}{l}\text { TBI survivors: }>16 \text {. } \\
\text { Must be clear of post- } \\
\text { traumatic amnesia. } \\
\text { Significant others: }>18 \text {, } \\
\text { knew the care recipient } \\
\text { prior to brain injury and } \\
\text { considered to be active } \\
\text { carer. }\end{array}$ & $\begin{array}{l}\text { Medically documented } \\
\text { TBI and community } \\
\text { dwelling. >18 years of } \\
\text { age. No longer } \\
\text { participating in rehab } \\
\text { programme. }\end{array}$ \\
\hline
\end{tabular}




\section{Appendix four: Details of the intervention in studies identified in systematic review}

Information in this table is adapted from the text of the papers, along with comments on missing information where relevant. Extended direct quotes from the papers are italicised and in quotation marks.

\begin{tabular}{|c|c|c|c|c|c|c|}
\hline Study & $\begin{array}{l}\text { Kolakowsky-Hayner et al } \\
2012 \text { (reference no. 22) }\end{array}$ & $\begin{array}{l}\text { Moreci } 1996 \text { (reference } \\
\text { no. 23) }\end{array}$ & $\begin{array}{l}\text { Hibbard et al } 2002 \\
\text { (reference no. 24) }\end{array}$ & $\begin{array}{l}\text { Hibbard and Cantor } \\
2005 \text { (reference no. 25) }\end{array}$ & $\begin{array}{l}\text { Hanks et al } 2012 \\
\text { (reference no. 26) }\end{array}$ & $\begin{array}{l}\text { Struchen et al } 2011 \\
\text { (reference no. 27) }\end{array}$ \\
\hline $\begin{array}{l}\text { Aims and } \\
\text { underpinning theory }\end{array}$ & $\begin{array}{l}\text { Improve the ability of an } \\
\text { individual with } \\
\text { disabilities to access } \\
\text { and maximally utilize the } \\
\text { services and programs } \\
\text { that are available in the } \\
\text { community. }\end{array}$ & $\begin{array}{l}\text { "Understanding the } \\
\text { difficulties that are } \\
\text { encountered, as well as } \\
\text { the breakthroughs } \\
\text { possible, we support } \\
\text { one another." }\end{array}$ & $\begin{array}{l}\text { "To reduce isolation by } \\
\text { providing social support } \\
\text { and validation of } \\
\text { personal experiences by } \\
\text { "someone who has been } \\
\text { there before."” } \\
\text { "With the aim of } \\
\text { increasing the validity } \\
\text { of research findings and } \\
\text { empowering consumers, } \\
\text { a paradigm of } \\
\text { participatory action } \\
\text { research (PAR) was } \\
\text { incorporated into all } \\
\text { aspects of the TBI-MPP. } \\
\text { Strengths of PAR } \\
\text { include the innovative } \\
\text { adaptation of methods } \\
\text { for use in a variety of } \\
\text { different contexts, } \\
\text { exploration of the } \\
\text { knowledge and } \\
\text { perceptions of } \\
\text { community members, } \\
\text { involving members } \\
\text { of the community as } \\
\text { active participants, and } \\
\text { facilitating the equitable } \\
\text { distribution of power in } \\
\text { the process of research } \\
\text { so that community } \\
\text { members are regarded } \\
\text { by themselves and }\end{array}$ & No details. & $\begin{array}{l}\text { To improve: (1) } \\
\text { emotional wellbeing; (2) } \\
\text { post-TBI quality of life; } \\
\text { and (3) community } \\
\text { integration. } \\
\text { "Using a participatory- } \\
\text { action research } \\
\text { approach, persons } \\
\text { with TBI and their } \\
\text { significant others who } \\
\text { were not directly } \\
\text { involved with this project } \\
\text { helped to develop a } \\
\text { satisfaction } \\
\text { questionnaire to } \\
\text { evaluate this program." }\end{array}$ & $\begin{array}{l}\text { Improving social } \\
\text { integration and } \\
\text { participation in adults } \\
\text { with TBI. }\end{array}$ \\
\hline
\end{tabular}




\begin{tabular}{|c|c|c|c|c|c|c|}
\hline & & & $\begin{array}{l}\text { others as being capable } \\
\text { of examining and } \\
\text { analysing their own } \\
\text { circumstances." }\end{array}$ & & & \\
\hline $\begin{array}{l}\text { Content and } \\
\text { components of } \\
\text { intervention delivery }\end{array}$ & $\begin{array}{l}\text { "Program staff consisted } \\
\text { of two physicians, a } \\
\text { Program Coordinator, a } \\
\text { Program Assistant, a } \\
\text { Vocational Counsellor, } \\
\text { and a Rehabilitation } \\
\text { Psychologist. The } \\
\text { Mentoring Program } \\
\text { Coordinator monitored } \\
\text { the progress of the } \\
\text { relationships on a semi- } \\
\text { monthly basis and } \\
\text { served as a liaison to a } \\
\text { Vocational Rehabilitation } \\
\text { Counsellor for purposes } \\
\text { of vocational planning. } \\
\text { The Rehabilitation } \\
\text { Psychologist assisted } \\
\text { with psychosocial } \\
\text { concerns that arose with } \\
\text { the mentee-mentor } \\
\text { relationship." }\end{array}$ & $\begin{array}{l}\text { The Peer Supporter } \\
\text { provides a listening ear } \\
\text { and a sensitive } \\
\text { awareness of the many } \\
\text { issues concerning TBI. } \\
\text { Individual structured } \\
\text { peer support visit in the } \\
\text { rehabilitation unit. Peer } \\
\text { supporters visit the } \\
\text { rehabilitation centre in } \\
\text { teams of two, three } \\
\text { nights each week for two } \\
\text { hours. Peer Supporters } \\
\text { also make phone calls to } \\
\text { offer support to } \\
\text { individuals and their } \\
\text { families who have left } \\
\text { the rehabilitation unit. }\end{array}$ & $\begin{array}{l}\text { "TBI "veterans" were } \\
\text { matched with individuals } \\
\text { with TBI or family } \\
\text { members to provide } \\
\text { emotional support, } \\
\text { knowledge about TBI } \\
\text { and resources, and } \\
\text { advocacy skills. The } \\
\text { programme was } \\
\text { designed to address } \\
\text { both the acute and long- } \\
\text { term adjustment needs } \\
\text { of individuals with TBI } \\
\text { and their family } \\
\text { members." }\end{array}$ & No details. & $\begin{array}{l}\text { Discussions in } \\
\text { mentoring sessions were } \\
\text { focused on: emotional } \\
\text { well-being; post-TBI } \\
\text { quality of life; and } \\
\text { community integration. } \\
\text { Mentors provided social } \\
\text { and emotional support, } \\
\text { helping the mentee gain } \\
\text { access to community } \\
\text { resources, and } \\
\text { discussion of any topics } \\
\text { related to TBI or } \\
\text { caregiving that the } \\
\text { mentee wanted to } \\
\text { discuss. } \\
\text { "Mentors were hired as } \\
\text { contingent employees } \\
\text { and involved in weekly } \\
\text { in-person supervision } \\
\text { from a psychologist, a } \\
\text { nurse, and community } \\
\text { outreach coordinator. } \\
\text { These supervisors were } \\
\text { available for 24-hour } \\
\text { emergency assistance." }\end{array}$ & $\begin{array}{l}\text { Goal of outings to foster } \\
\text { increased social } \\
\text { networking for the PP } \\
\text { through introductions to } \\
\text { people, activities and } \\
\text { community resources. } \\
\text { On-call therapist spoke } \\
\text { to SPMs by phone at } \\
\text { least once per week and } \\
\text { often assisted with } \\
\text { problem-solving. Was } \\
\text { always available by } \\
\text { pager in the event of an } \\
\text { emergency and provided } \\
\text { training booster } \\
\text { sessions. }\end{array}$ \\
\hline $\begin{array}{l}\text { Timing (time post- } \\
\text { injury intervention was } \\
\text { delivered) }\end{array}$ & $\begin{array}{l}\text { No specific details. } \\
\text { Mentees average of } 503 \\
\text { days post-injury. }\end{array}$ & $\begin{array}{l}\text { Initial contact in } \\
\text { rehabilitation unit. }\end{array}$ & $\begin{array}{l}\text { Various stages of } \\
\text { recovery. Not specifically } \\
\text { stated. }\end{array}$ & No details. & $\begin{array}{l}\text { Participants were } \\
\text { contacted by their peer } \\
\text { mentors prior to } \\
\text { discharge or within } 2 \\
\text { days of discharge from } \\
\text { inpatient rehabilitation. }\end{array}$ & $\begin{array}{l}\text { Various stages. Mentees } \\
\text { a median of } 1.6 \text { years } \\
\text { post injury. }\end{array}$ \\
\hline Matching criteria & $\begin{array}{l}\text { Each mentee was } \\
\text { matched with a } \\
\text { community-based } \\
\text { mentor who may or may } \\
\text { not have a disability } \\
\text { although efforts were } \\
\end{array}$ & $\begin{array}{l}\text { Not applicable. Peer } \\
\text { supporters visit several } \\
\text { patients in each visit. } \\
\text { Long term relationships } \\
\text { encouraged but no }\end{array}$ & $\begin{array}{l}\text { Based on needs of } \\
\text { participant. Criteria } \\
\text { included; similar } \\
\text { demographic } \\
\text { background; similar } \\
\text { marital or family status; }\end{array}$ & No details. & $\begin{array}{l}\text { Matched by the study } \\
\text { coordinator by sex and } \\
\text { role (e.g., person with } \\
\text { TBI vs significant other), } \\
\text { and each mentee only } \\
\text { had } 1 \text { mentor. }\end{array}$ & $\begin{array}{l}\text { "Social mentors were } \\
\text { matched to their PPS on } \\
\text { the basis of group } \\
\text { consensus of the } \\
\text { research team using the } \\
\text { following criteria: }\end{array}$ \\
\hline
\end{tabular}




\begin{tabular}{|c|c|c|c|c|c|c|}
\hline & $\begin{array}{l}\text { made to recruit } \\
\text { individuals with } \\
\text { disabilities to serve as } \\
\text { mentors. Matched for } \\
\text { age, gender, disability } \\
\text { type, location, interests, } \\
\text { etc. }\end{array}$ & $\begin{array}{l}\text { details provided on } \\
\text { matching for these. }\end{array}$ & $\begin{array}{l}\text { similar injury history and } \\
\text { effects; similar interests } \\
\text { (including religious } \\
\text { beliefs); mentor's ability } \\
\text { to meet the specific } \\
\text { psychological needs of } \\
\text { the partner. }\end{array}$ & & & $\begin{array}{l}\text { geographical proximity, } \\
\text { age, gender, and } \\
\text { interests. SPMs were } \\
\text { allowed to mentor } 1 \text { or } \\
\text { more PPs over the } \\
\text { course of the study but } \\
\text { could not be assigned to } \\
\text { more than } 1 \text { PP } \\
\text { simultaneously." "Every } \\
\text { effort was made to find a } \\
\text { mentor-partner match } \\
\text { that would best facilitate } \\
\text { increased opportunities } \\
\text { for social contact." }\end{array}$ \\
\hline $\begin{array}{l}\text { Frequency, duration, } \\
\text { intensity and fidelity of } \\
\text { implementation. }\end{array}$ & $\begin{array}{l}\text { Minimum of } 3 \text { contacts } \\
\text { per month through in- } \\
\text { person, telephone, or } \\
\text { electronic mail methods. } \\
\text { Not time limited. Formal } \\
\text { exit from the program } \\
\text { was scheduled to occur } \\
4 \text { months after the } \\
\text { individual with disability } \\
\text { attempted to return to } \\
\text { post-secondary } \\
\text { education or } \\
\text { employment. Some } \\
\text { pairings continued their } \\
\text { relationship actually } \\
\text { outside the auspices of } \\
\text { the formal mentoring } \\
\text { program. }\end{array}$ & $\begin{array}{l}\text { Visits occur three nights } \\
\text { each week from } 18.00 \mathrm{~h} \\
\text { to } 20.00 \mathrm{~h} \text {. Two hours is } \\
\text { enough time to visit with } \\
\text { at least four patients and } \\
\text { their families. } \\
\text { The relationship } \\
\text { between peers can grow } \\
\text { into a long term } \\
\text { connection and reduce } \\
\text { the chance for isolation } \\
\text { and depression. }\end{array}$ & $\begin{array}{l}\text { The duration of the } \\
\text { partnership and its } \\
\text { intensity are mutual } \\
\text { decisions of the mentor } \\
\text { and his or her partner. } \\
\text { On average, mentors } \\
\text { and partners } \\
\text { participating in the study } \\
\text { had } 13 \text { contacts with } \\
\text { mentors, with wide } \\
\text { variation in the number } \\
\text { of contacts made per } \\
\text { partnership (SD = } \\
12.77) \text {. One partnership } \\
\text { was excluded from the } \\
\text { analysis as an outlier } \\
\text { because they had more } \\
\text { than } 108 \text { documented } \\
\text { contacts. }\end{array}$ & No details. & $\begin{array}{l}\text { Mentors arranged for a } \\
\text { meeting within } 2 \text { weeks } \\
\text { of initial contact and } \\
\text { were requested to meet } \\
\text { and/or talk via telephone } \\
\text { at least weekly for the } \\
\text { first month, biweekly for } \\
\text { the next } 2 \text { to } 3 \text { months, } \\
\text { and then monthly for the } \\
\text { remainder of the first } \\
\text { year. Contact more } \\
\text { frequent than these } \\
\text { minimum guidelines was } \\
\text { encouraged as } \\
\text { appropriate. } \\
\text { Formal mentoring lasted } \\
\text { for } 1 \text { year, although } \\
\text { mentees were } \\
\text { encouraged to continue } \\
\text { the relationship with } \\
\text { their mentors during the } \\
\text { second year if desired. } \\
\text { Contacts were mostly } 5 \\
\text { to } 15 \text { minutes ( } 36 \%) \text {, } \\
\text { followed by contacts } \\
\text { lasting } 16 \text { to } 30 \text { minutes } \\
\text { ( } 30 \%), 31 \text { to } 60 \text { minutes } \\
(19 \%) \text {, and } 15 \% \text { greater } \\
\text { than an hour. }\end{array}$ & $\begin{array}{l}\text { Active peer mentoring } \\
\text { occurred over a 3-month } \\
\text { period. Mentor (SPM) } \\
\text { responsible for making } \\
\text { initial contact within } 1 \\
\text { week after receiving } \\
\text { their partner's (PP) } \\
\text { details. SPMs were } \\
\text { asked to set up initial } \\
\text { outing. Additional } \\
\text { contacts could be } \\
\text { initiated by either party. } \\
\text { SPM responsible for } \\
\text { ensuring that each } \\
\text { respective PP } \\
\text { participated in a } \\
\text { minimum of } 2 \text { outings } \\
\text { per month. } \\
\text { Only half of the SPM-PP } \\
\text { matches met for the } \\
\text { minimum number of } \\
\text { outings (6), and only } 2 \\
\text { matches exceeded the } \\
\text { minimum outing } \\
\text { requirements. }\end{array}$ \\
\hline
\end{tabular}




\begin{tabular}{|c|c|c|c|c|c|c|}
\hline & & & & & $\begin{array}{l}\text { Minimum number of } \\
\text { contacts should be } 18 \text {. } \\
\text { Actual number of } \\
\text { contacts averaged } 5.4 \\
\text { so on average did not } \\
\text { meet minimum } \\
\text { guidelines. }\end{array}$ & \\
\hline Mentor training & $\begin{array}{l}\text { Mentors underwent a } \\
\text { training curriculum and } \\
\text { refresher sessions } \\
\text { throughout the program } \\
\text { under the facilitation of a } \\
\text { Rehabilitation } \\
\text { Psychologist and the } \\
\text { Program Coordinator. } \\
\text { Training was based on } \\
\text { the structure of the } \\
\text { traumatic brain injury } \\
\text { (TBI) and spinal cord } \\
\text { injury (SCI) Peer } \\
\text { Support Program } \\
\text { volunteer training at our } \\
\text { facility (no further details } \\
\text { on this provided). }\end{array}$ & $\begin{array}{l}\text { "Hospital } \\
\text { neuropsychologist and } \\
\text { experts in the area of } \\
\text { grief process, active } \\
\text { listening, } \\
\text { communication, hospital } \\
\text { procedures, and basic } \\
\text { brain injury education } \\
\text { train the peer supporters } \\
\text { once per year. Training } \\
\text { is an ongoing process. } \\
\text { During bi-monthly } \\
\text { training meetings, the } \\
\text { volunteer Peer } \\
\text { Supporters are given an } \\
\text { opportunity to discuss } \\
\text { challenges to providing } \\
\text { support, enhancing } \\
\text { communication skills, } \\
\text { basic procedures of the } \\
\text { job, and important } \\
\text { issues regarding grief, } \\
\text { TBl and resources. } \\
\text { There is also a social } \\
\text { component to the bi- } \\
\text { monthly meetings to } \\
\text { provide an opportunity } \\
\text { for the volunteers to get } \\
\text { to know each other } \\
\text { better. A cohesive group } \\
\text { is important and allows } \\
\text { the peer supporters to } \\
\text { receive emotional } \\
\text { support from each } \\
\text { other." }\end{array}$ & $\begin{array}{l}\text { "A mentor training } \\
\text { manual was developed. } \\
\text { A series of } 8 \text { full-day } \\
\text { mentor training } \\
\text { workshops was held } \\
\text { over the course of the } \\
\text { first } 2 \text { years of the } \\
\text { project. At these } \\
\text { workshops, mentors } \\
\text { received training } \\
\text { focused on enhancing } \\
\text { their communication, } \\
\text { listening, and advocacy } \\
\text { skills and increasing } \\
\text { their knowledge of TBI } \\
\text { and community } \\
\text { resources. Because } \\
\text { most communication } \\
\text { between partners and } \\
\text { mentors is by telephone, } \\
\text { training emphasized } \\
\text { communication skills } \\
\text { using this modality." } \\
\text { Training of mentors } \\
\text { focused on techniques } \\
\text { to increase a network of } \\
\text { support from family, } \\
\text { friends, and community } \\
\text { members in potential } \\
\text { partners. } \\
\text { A subgroup of mentors } \\
\text { received additional } \\
\text { training in hospital } \\
\text { advocacy skills to play a }\end{array}$ & No details. & $\begin{array}{l}\text { Curriculum and training } \\
\text { manuals included: (1) } \\
\text { introduction to the peer- } \\
\text { mentoring project; (2) } \\
\text { effects of TBI, and } \\
\text { disability awareness; (3) } \\
\text { practical skills beneficial } \\
\text { in any helping } \\
\text { relationship); (4) practice } \\
\text { of new skills with } 2 \text { case } \\
\text { studies and feedback } \\
\text { from supervisors and } \\
\text { other trainees; and (5) } \\
\text { resources from the State } \\
\text { of Michigan TBI } \\
\text { Resource Guide } \\
\text { developed by the Health } \\
\text { Related Services } \\
\text { Administration-funded } \\
\text { State of Michigan TBI } \\
\text { grantee program. } \\
\text { Mentors participated in } \\
20 \text { hours of training, and } \\
\text { all mentors were trained } \\
\text { at the same time. } \\
\text { Interactive training } \\
\text { consisted of (1) } \\
\text { modelling interviewing } \\
\text { skills with a supervisor } \\
\text { and fellow trainees; (2) } \\
\text { telephone role playing; } \\
\text { (3) discussion of what is } \\
\text { and what is not } \\
\text { mentoring; (4) } \\
\text { communication skills } \\
\text { and active listening; and }\end{array}$ & $\begin{array}{l}\text { "Initial training was } \\
\text { conducted in two 2-hour } \\
\text { group sessions led by a } \\
\text { neuropsychologist and a } \\
\text { consumer representative } \\
\text { with TBI who was part of } \\
\text { the research team. This } \\
\text { training was } \\
\text { supplemented by a } \\
\text { written manual and by } \\
\text { additional booster } \\
\text { training as needed. } \\
\text { Group training sessions } \\
\text { included didactic } \\
\text { presentation, discussion, } \\
\text { and role-play of specific } \\
\text { skill-building activities." } \\
\text { Specific components of } \\
\text { the formal training } \\
\text { included; review of the } \\
\text { SPM role and "ground } \\
\text { rules"; understanding } \\
\text { TBI; outlining common } \\
\text { challenges following } \\
\text { brain injury and ways to } \\
\text { manage these; } \\
\text { reviewing skills that may } \\
\text { enhance social } \\
\text { functioning and ideas for } \\
\text { facilitating skill growth } \\
\text { for PP; handling difficult } \\
\text { communication issues } \\
\text { and crisis situations; } \\
\text { review of documentation } \\
\text { responsibilities for the } \\
\text { study. }\end{array}$ \\
\hline
\end{tabular}




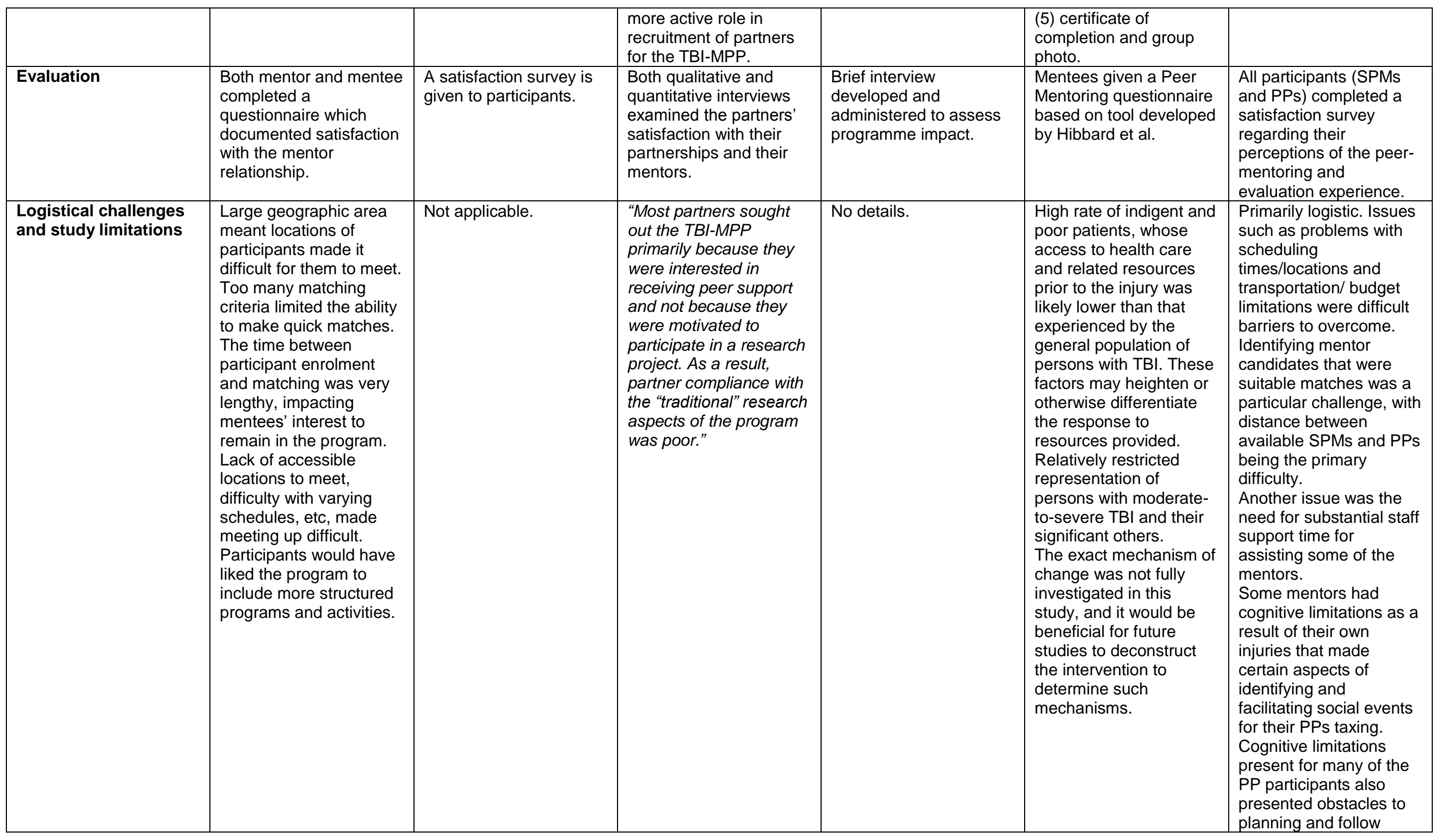




\begin{tabular}{|c|c|c|c|c|c|c|}
\hline & & & & & & $\begin{array}{l}\text { through, with issues, } \\
\text { such as failing to } \\
\text { remember some of the } \\
\text { ground rules and failing } \\
\text { to call mentors. }\end{array}$ \\
\hline $\begin{array}{l}\text { Details of social and } \\
\text { leisure re-engagement }\end{array}$ & $\begin{array}{l}\text { Details provided of } \\
\text { number of times mentors } \\
\text { logged their mentees } \\
\text { interest in a specific } \\
\text { topic. Relaxation ( } 379 \\
\text { times); Family/friends } \\
\text { (358); Relationship } \\
\text { issues (354). } \\
\text { Significant community } \\
\text { integration and } \\
\text { independence } \\
\text { improvements were } \\
\text { noted for program } \\
\text { participants (CHART } \\
\text { Mobility and Cognitive } \\
\text { Independence, M2PI, } \\
\text { DRS, and SRS). }\end{array}$ & $\begin{array}{l}\text { No information. Author } \\
\text { states that more } \\
\text { research is needed on } \\
\text { effect of peer relations } \\
\text { on social isolation and } \\
\text { depression in people } \\
\text { with TBI. }\end{array}$ & $\begin{array}{l}\text { Impact on social support } \\
\text { from friends was } \\
\text { reported by a small } \\
\text { group of participants (a } \\
\text { "major impact" by } 18 \% \\
\text { of individuals and } 11 \% \\
\text { of family members, with } \\
\text { "some impact" for an } \\
\text { additional } 22 \% \text { of family } \\
\text { members). } \\
\text { Minimal impact was } \\
\text { noted on enhancing } \\
\text { social support from the } \\
\text { community at large ( } 11 \% \\
\text { "major impact" by family } \\
\text { members and } 9 \% \text { "some } \\
\text { impact" for individuals). }\end{array}$ & No details. & $\begin{array}{l}\text { The majority of mentees } \\
\text { were satisfied with their } \\
\text { experience, and felt that } \\
\text { it helped with social } \\
\text { support. }\end{array}$ & $\begin{array}{l}\text { Goal of outings to foster } \\
\text { increased social } \\
\text { networking for the PP } \\
\text { through introductions to } \\
\text { people, activities and } \\
\text { community resources. } \\
\text { Social integration was } \\
\text { not shown to } \\
\text { significantly improve, } \\
\text { although changes in } \\
\text { social integration scores } \\
\text { were in the predicted } \\
\text { direction for mentored } \\
\text { ppts. Small positive } \\
\text { changes were noted for } \\
\text { mentored PPs in the } \\
\text { areas of social network } \\
\text { size, participation in } \\
\text { highly valued activities, } \\
\text { and activities involving } \\
\text { persons other than } \\
\text { family; however, these } \\
\text { changes were not } \\
\text { statistically significant } \\
\text { and were also noted for } \\
\text { those in the WL. }\end{array}$ \\
\hline
\end{tabular}




\section{Appendix five: Outcome measures, follow-up periods, results and conclusions of studies identified in systematic review}

Information in this table is adapted from the text of the papers, along with comments on missing information where relevant. Extended direct quotes from the papers are italicised and in quotation marks.

\begin{tabular}{|c|c|c|c|c|c|c|}
\hline Study & $\begin{array}{l}\text { Kolakowsky-Hayner et al } \\
2012 \text { (reference no. 22) }\end{array}$ & $\begin{array}{l}\text { Moreci } 1996 \text { (reference } \\
\text { no. 23) }\end{array}$ & $\begin{array}{l}\text { Hibbard et al } 2002 \\
\text { (reference no. 24) }\end{array}$ & $\begin{array}{l}\text { Hibbard and Cantor } \\
2005 \text { (reference no. 25) }\end{array}$ & $\begin{array}{l}\text { Hanks et al } 2012 \\
\text { (reference no. 26) }\end{array}$ & $\begin{array}{l}\text { Struchen et al 2011 } \\
\text { (reference no. 27) }\end{array}$ \\
\hline Outcome measures & $\begin{array}{l}\text { Disability Rating Scale } \\
\text { (DRS); the Participation } \\
\text { Index of the Mayo- } \\
\text { Portland Adaptability } \\
\text { Inventory - Version } 4 \\
\text { (M2PI); the Supervision } \\
\text { Rating Scale (SRS); the } \\
\text { Craig Handicap } \\
\text { Assessment and } \\
\text { Reporting Technique - } \\
\text { Short Form (CHART- } \\
\text { SF), and the Diener } \\
\text { Satisfaction with Life } \\
\text { Scale (SWLS). } \\
\text { Programme satisfaction } \\
\text { questionnaire. }\end{array}$ & Not applicable. & $\begin{array}{l}\text { Retrospective structured } \\
\text { interview assessing self- } \\
\text { reported impacts of peer } \\
\text { support on } \\
\text { empowerment, quality of } \\
\text { life, mood, skills and } \\
\text { knowledge, and social } \\
\text { supports; an in-depth } \\
\text { qualitative interview with } \\
\text { a subgroup of family } \\
\text { members focused on the } \\
\text { specific } \\
\text { benefits/limitations of the } \\
\text { program. Interview } \\
\text { questions adapted } \\
\text { from four existing } \\
\text { measures: the } \\
\text { Questionnaire } \\
\text { on Resources and } \\
\text { Stress-Short Form } \\
\text { (QRS-SF), the } \\
\text { Frequency of Family } \\
\text { Coping } \\
\text { Behaviours (FCB), the } \\
\text { Social Support } \\
\text { Questionnaire } \\
\text { Short Form (SSQ-SR), } \\
\text { and the } \\
\text { Empowerment Scale. } \\
\text { Validation of the }\end{array}$ & $\begin{array}{l}\text { Beck Depression } \\
\text { Inventory-II, Beck } \\
\text { Anxiety Inventory, coping } \\
\text { and empowerment } \\
\text { measures, brief interview } \\
\text { developed to assess } \\
\text { program impact. }\end{array}$ & $\begin{array}{l}\text { Peer Mentoring } \\
\text { Questionnaire; Brief } \\
\text { Symptom Inventory-18; } \\
\text { Family Assessment } \\
\text { Device; Coping Inventory } \\
\text { for Stressful Situations; } \\
\text { Short Michigan Alcohol } \\
\text { Screening Test; Medical } \\
\text { Outcomes Study 12-Item } \\
\text { Short-Form Health } \\
\text { Survey; and Community } \\
\text { Integration Measure. }\end{array}$ & $\begin{array}{l}\text { CHART-SF (Physical } \\
\text { Independence, Cognitive } \\
\text { Independence, Mobility, } \\
\text { Occupation, and Social } \\
\text { Integration subscales); } \\
\text { Social Activity Interview } \\
\text { (SAI); Center for } \\
\text { Epidemiological Studies } \\
\text { Depression Scale; UCLA } \\
\text { Loneliness Scale - } \\
\text { Version 3; 6-item } \\
\text { Interpersonal Support } \\
\text { Evaluation List; } \\
\text { Satisfaction with Life } \\
\text { Scale; Weekly Social } \\
\text { Activity Survey; Peer } \\
\text { Partner Satisfaction } \\
\text { Survey; Mentor } \\
\text { Satisfaction Survey. }\end{array}$ \\
\hline
\end{tabular}




\begin{tabular}{|c|c|c|c|c|c|c|}
\hline & & & $\begin{array}{l}\text { reliability and construct } \\
\text { validity of the } \\
\text { quantitative interview as } \\
\text { a whole was deferred. }\end{array}$ & & & \\
\hline Follow up periods & $\begin{array}{l}\text { Minimum of four } \\
\text { assessments: At time of } \\
\text { enrolment; three months; } \\
\text { every three months until } \\
\text { attempted entry to } \\
\text { employment or post- } \\
\text { secondary education; } \\
\text { four months after entry to } \\
\text { employment or } \\
\text { education. }\end{array}$ & Not applicable. & Post study completion. & $\begin{array}{l}\text { Baseline and after } \\
\text { programme completion } \\
\text { (no further details). }\end{array}$ & $\begin{array}{l}12 \text { months after } \\
\text { completion of mentoring. } \\
\text { Comparison was } \\
\text { between the groups. }\end{array}$ & $\begin{array}{l}\text { One month baseline and } \\
\text { three-month peer } \\
\text { mentoring period. } \\
\text { Equivalent four-month } \\
\text { period for wait list } \\
\text { participants. }\end{array}$ \\
\hline Results & $\begin{array}{l}\text { "Of those with education } \\
\text { goals, } 23 / 53 \text { achieved } \\
\text { educational goals and } \\
7 / 53 \text { achieved } \\
\text { employment goals. Of } \\
\text { those with vocational } \\
\text { goals, } 5 / 12 \text { achieved } \\
\text { vocational goals and } \\
1 / 12 \text { achieved } \\
\text { educational goals. Of } \\
\text { those with both goals, } \\
5 / 12 \text { achieved } \\
\text { educational goals and } \\
1 / 12 \text { achieved vocational } \\
\text { goals. Significant } \\
\text { community integration } \\
\text { and independence } \\
\text { improvements were } \\
\text { noted for program } \\
\text { participants (CHART } \\
\text { Mobility and Cognitive } \\
\text { Independence, M2PI, } \\
\text { DRS, and SRS)." }\end{array}$ & Not applicable. & $\begin{array}{l}\text { "Participants in the peer } \\
\text { support program } \\
\text { reported positive impacts } \\
\text { of peer support on } \\
\text { increasing their } \\
\text { knowledge of TBI, } \\
\text { enhancing their overall } \\
\text { quality of life, improving } \\
\text { their general outlook, } \\
\text { and enhancing their } \\
\text { ability to cope with } \\
\text { depression post TBI. The } \\
\text { peer support program } \\
\text { was reported to have } \\
\text { had a minimal impact on } \\
\text { enhancing social support } \\
\text { from families, friends, } \\
\text { and the community, with } \\
\text { varying impacts noted on } \\
\text { levels of happiness, } \\
\text { coping with anger and } \\
\text { anxiety, communication } \\
\text { with professionals, and } \\
\text { control over one's life. } \\
\text { Qualitative analysis }\end{array}$ & $\begin{array}{l}\text { "After program } \\
\text { participation, the partner } \\
\text { group showed } \\
\text { statistically significant } \\
\text { improvements in } \\
\text { depression }(P<0.05), \\
\text { empowerment }(P< \\
0.05) \text {, life satisfaction ( } P \\
<0.05), \text { coping ( } P \\
<0.05), \text { and } \\
\text { communication with } \\
\text { health care professionals } \\
(P<0.01) \text {. The controls } \\
\text { exhibited no significant } \\
\text { changes. There was a } \\
\text { significant group by time } \\
\text { interaction for } \\
\text { depression }(P=0.042), \\
\text { empowerment }(P= \\
0.007), \text { life satisfaction } \\
(P=0.032), \text { coping }(P= \\
0.018), \text { and } \\
\text { communication with } \\
\text { health care professionals } \\
(P=0.001) \text {." }\end{array}$ & $\begin{array}{l}\text { "Eighty-eight percent of } \\
\text { individuals who were } \\
\text { involved in the mentoring } \\
\text { program reported } \\
\text { positive experiences. } t \\
\text { tests revealed that } \\
\text { among persons with TBI, } \\
\text { individuals who received } \\
\text { mentoring had } \\
\text { significantly better } \\
\text { behavioural control and } \\
\text { less chaos in the living } \\
\text { environment ( } P=.04), \\
\text { lower alcohol use ( } P \\
=.01), \text { less emotion- } \\
\text { focused ( } P=.04) \text { and } \\
\text { avoidance coping ( } P \\
=.03), \text { and good physical } \\
\text { quality of life }(P=.04) \\
\text { compared with those } \\
\text { who did not receive } \\
\text { mentoring. Among } \\
\text { significant others, } \\
\text { mentored individuals } \\
\text { demonstrated greater }\end{array}$ & $\begin{array}{l}\text { "Both SPM and PP } \\
\text { participants reported } \\
\text { high satisfaction with the } \\
\text { mentoring program. } \\
\text { Statistically significant } \\
\text { improvements in } \\
\text { perceived social support } \\
\text { after mentoring were } \\
\text { observed for the } \\
\text { mentored group } \\
\text { compared to WL } \\
\text { participants; however, an } \\
\text { increase in depressive } \\
\text { symptoms was also } \\
\text { observed. While } \\
\text { significant improvements } \\
\text { in social activity level } \\
\text { and social network size } \\
\text { were not found, a trend } \\
\text { toward increased } \\
\text { satisfaction with social } \\
\text { life was present for } \\
\text { mentored participants." }\end{array}$ \\
\hline
\end{tabular}




\begin{tabular}{|c|c|c|c|c|c|c|}
\hline & $\begin{array}{l}57 \text { ppts had TBI, of } \\
\text { which } 30 \text { successfully } \\
\text { completed the } \\
\text { programme. }\end{array}$ & & $\begin{array}{l}\text { suggests the merits of } \\
\text { this type of community- } \\
\text { based support." }\end{array}$ & & $\begin{array}{l}\text { community integration ( } P \\
=.03) \text { than the non- } \\
\text { mentored control group." }\end{array}$ & $\begin{array}{l}\text { Improvements in social } \\
\text { integration scores were } \\
\text { observed for active peer } \\
\text { partners, but were non- } \\
\text { significant. }\end{array}$ \\
\hline Conclusions & $\begin{array}{l}\text { "Overall, findings } \\
\text { suggest that mentoring } \\
\text { can be beneficial toward } \\
\text { achieving the goals of } \\
\text { post-secondary } \\
\text { education, employment } \\
\text { and community } \\
\text { independence for } \\
\text { individuals with } \\
\text { disabilities; specifically } \\
\text { those with traumatic } \\
\text { brain injury, spinal cord } \\
\text { injury and other } \\
\text { neurological disorders." }\end{array}$ & $\begin{array}{l}\text { The importance of } \\
\text { individual peer support } \\
\text { visits is supported by } \\
\text { positive conversations } \\
\text { with the patients and } \\
\text { families who receive } \\
\text { support. } \\
\text { The TBI peer support } \\
\text { program significantly } \\
\text { affects the lives of the } \\
\text { peer supporters through } \\
\text { a feeling of self-esteem. }\end{array}$ & $\begin{array}{l}\text { Preliminary data suggest } \\
\text { that peer support is a } \\
\text { promising approach to } \\
\text { enhancing coping for } \\
\text { both individuals and their } \\
\text { family members after } \\
\text { TBI. }\end{array}$ & $\begin{array}{l}\text { The program seems to } \\
\text { have been associated } \\
\text { with significant } \\
\text { improvements in partner } \\
\text { functioning in multiple } \\
\text { key areas as compared } \\
\text { to controls. }\end{array}$ & $\begin{array}{l}\text { "Mentoring can be an } \\
\text { effective way to benefit } \\
\text { mood and healthy coping } \\
\text { after TBI, and it can help } \\
\text { to prevent maladaptive } \\
\text { behaviours, such as } \\
\text { substance abuse and } \\
\text { behavioural dyscontrol, } \\
\text { in the living situation." } \\
\text { "Future research should } \\
\text { address which } \\
\text { components of education } \\
\text { about recovery from } \\
\text { brain injury and } \\
\text { adjustment to living with } \\
\text { such injuries might be } \\
\text { most helpful to persons } \\
\text { with TBI and their } \\
\text { significant others." }\end{array}$ & $\begin{array}{l}\text { "Satisfaction ratings for } \\
\text { the SPM program were } \\
\text { uniformly high and } \\
\text { selected positive findings } \\
\text { encourage further } \\
\text { investigation of social } \\
\text { mentoring as an } \\
\text { intervention to effect } \\
\text { improvements in social } \\
\text { integration. Small } \\
\text { sample size and reduced } \\
\text { "dosage" of mentor } \\
\text { interactions were } \\
\text { limitations of this pilot } \\
\text { study." }\end{array}$ \\
\hline
\end{tabular}


Figure

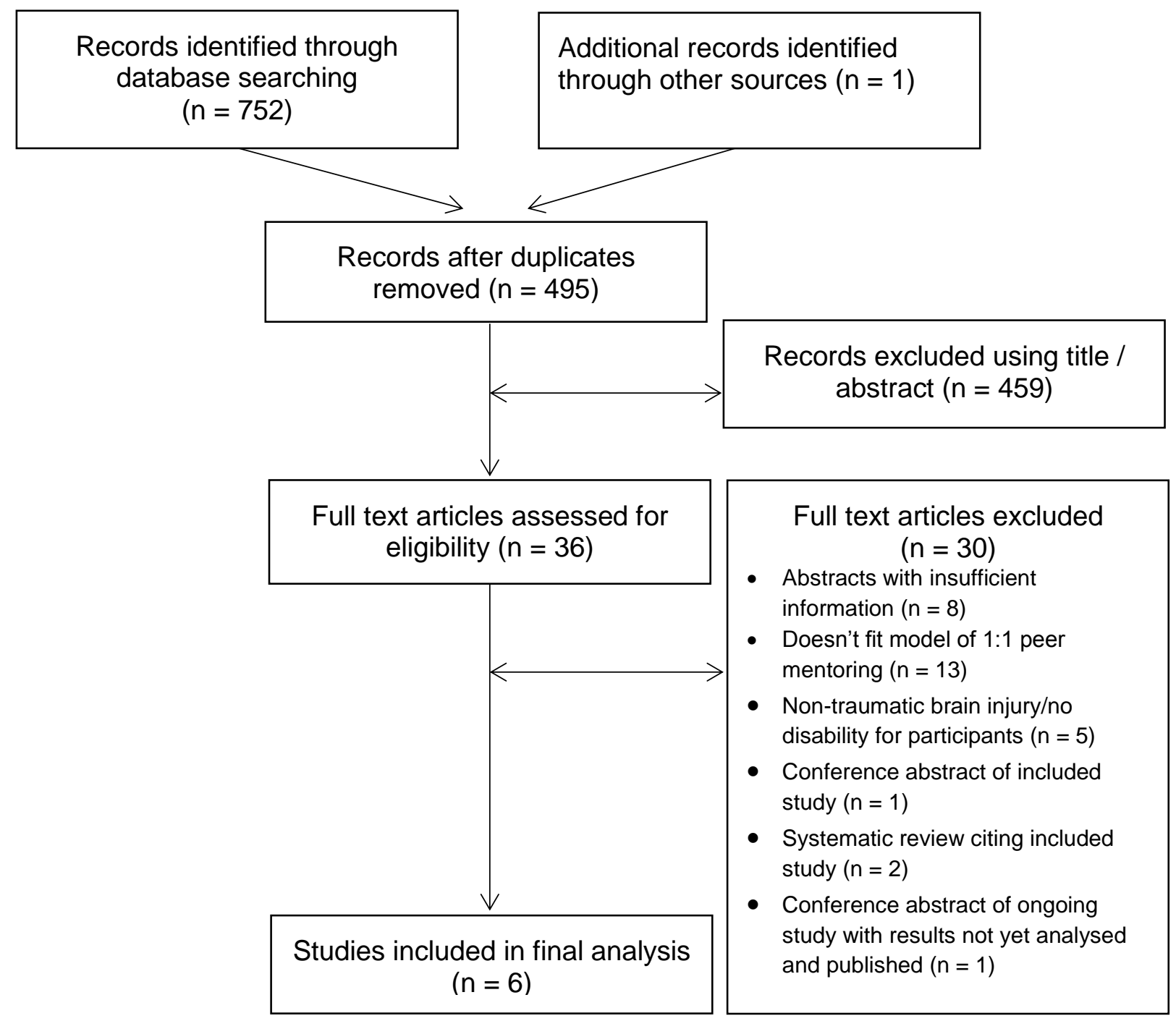

Figure 1: Flow diagram of study selection process 